\title{
„Dvije osobe ulaze \\ za umjetničko oslikavanje". Etnografija zatvora kao mjesta umjetnosti
}

"Two Persons Coming in for Artistic Painting."

\section{The Ethnography of Prison as Places of Art}


IZVORNI ZNANSTVENI RAD

Primljen: 3.5.2020.

Prihvaćen: 8.6.2020.

DOI: $10.31664 / z u .2020 .106 .10$

\section{APSTRAKT}

U središtu su članka četiri umjetničke intervencije koje su početkom 2019. godine izvedene u Zatvoru u Zagrebu u cilju estetizacije zatvorskog prostora. Rad se temelji na kvalitativnom etnografskom istraživanju koje je provedeno tijekom oslikavanja u navedenom zatvoru, u cilju razumijevanja: a) umjetničkog koncepta i nastajanja umjetničkog djela u zatvorskim prostorima, b) dinamike i značenja koju umjetničko djelo u zatvoru izaziva te c) promjene doživljaja kako pojedinačnih zatvorskih prostora tako i šire društvene percepcije o zatvorskom sustavu. Pristupi istraživanju i interpretaciji proizlaze iz antropologije prostora i mjesta te antropologije umjetnosti. Istraživanjem se analiziraju društveni, interakcijski, edukativni, estetizirajući, terapijski i afektivni učinci konkretnih umjetničkih intervencija u zatvoru. Poseban je interes fokusiran prema odnosima koji postoje ili se mijenjaju tijekom intervencija između svih uključenih aktera (umjetnici, razni profili djelatnika u zatvoru, zatvorenici). Ključan doprinos kulturnoantropoloških istraživanja proizlazi iz sposobnosti etnografije da bilježi i promišlja umjetnost ostvarenu kao relacijsku i komunikacijsku aktivnost, a u smislu primjene etnografskog istraživanja, riječ je o novitetu u istraživanju hrvatskih zatvorskih sustava.

KLJUČNE RIJEČI

Zatvor u Zagrebu, umjetnost, estetizacija prostora, kvalitativna istraživanja, etnografija, etnologija i kulturna antropologija
ORIGINAL SCIENTIFIC PAPER

Received: May 3, 2020

Accepted: June 8, 2020

DOI: $10.31664 / z u .2020 .106 .10$

SUMMARY

The article focuses on art interventions that were carried out in the Prison in Zagreb, popularly called Remetinec, at the beginning of 20I9, with the aim of aestheticizing prison space. It is based on cultural anthropological perspectives, and qualitative ethnographic research conducted in the course of the artistic project organized by the Croatian Association of Artists and led by Melinda Šefčić. The research approaches are grounded in current trends and tendencies in the anthropology of space and place and the anthropology of art. Its objectives are to understand: a) the artistic concept and the creation of art in the prison context, b) the dynamics and meanings triggered by artistic interventions in prison, and c) the ways in which the sense of that specific prison space, as well as the overall perception of the penal system, are being transformed through art.

\section{Valentina Gulin Zrnić}

Institut za etnologiju i folkloristiku / Institute of Ethnology and Folklore Research

\section{Sanja Potkonjak}

Odsjek za etnologiju i kulturnu antropologiju, Filozofski fakultet Sveučilišta u Zagrebu /

Department of Ethnology and Cultural Anthropology, Faculty of Humanities and Social Sciences, University of Zagreb

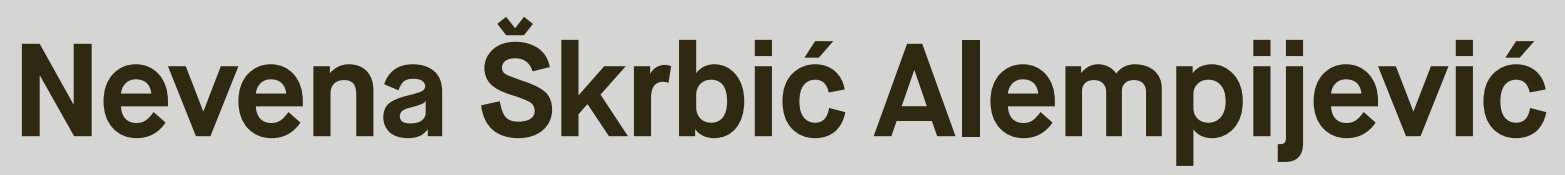

Odsjek za etnologiju i kulturnu antropologiju, Filozofski fakultet Sveučilišta u Zagrebu /

Department of Ethnology and Cultural Anthropology, Faculty of Humanities and Social Sciences, University of Zagreb 
The research centres on the work of four artists who conceptualized and produced their paintings on Remetinec Prison walls. Goran Rakić, Ivan Oštarčević Zgubljen, Dominik Vuković and Slaven Lunar Kosanović have integrated their artwork into well-frequented, communal and joint prison spaces: at the prison entry, along the corridors that lead to meeting rooms, in the therapy room and the courtyard-the locations that are regularly used by different agents (judicial police, members of technical, administrative and expert staff, and prisoners). This allowed the researchers to follow their reactions to the art creation, but also the effects that the interventions had on prison staff and prisoners who used the spaces for their everyday practices (which span from openness to art interventions and the recognition of their potential use for therapeutic purposes, to disapproval and the expressed attitude that artists should respond more directly to the interests of space users).

The authors discuss what it means to turn the prison into a site for art and a place of ethnographic research. By doing so, they point to the mainstream perception of prison as a place of isolation, punishment, control and surveillance, which is juxtaposed with the idea of "a colourful prison" represented in this artistic project. In this research, attention is paid to the social, affective, interactive, educational, aestheticizing and therapeutic effects of concrete artistic interventions in a prison. The starting point is the notion that transformative potential of art is not immanent to an artwork. Its agency rather stems from a complex network of diverse social agents, cultural policies, local and global knowledge systems, ways of life, and personal and collective experiences. The emphasis is thus placed on the relations between humans and space, as well as between the people present in prison space, which are established, negotiated and changed by art.

By intertwining the issues of prison space-making and art-making, this research poses a novelty in the research of Croatian penal system, which has so far been linked mostly to legal sciences, criminology, education and rehabilitation sciences, social work, psychology and the like. It also enriches the studies of art by emphasising its contextual dimension, by indicating how spatial imageries affect the artistic process and which actions, interactions and reactions are stimulated by the interventions. The main contribution of this cultural anthropological research derives from the capability of ethnography to record and interpret art as a relational and communication-based activity. Such an approach enables the researchers to grasp the mechanisms by which space is changed through its aestheticization, and ways in which space users are becoming more sensitized to change and to facing and questioning the normative expectations from both the prison space and the people in it.

\section{KEYWORDS}

The Prison in Zagreb, aestheticization of space, qualitative research, ethnography, ethnology and cultural anthropology

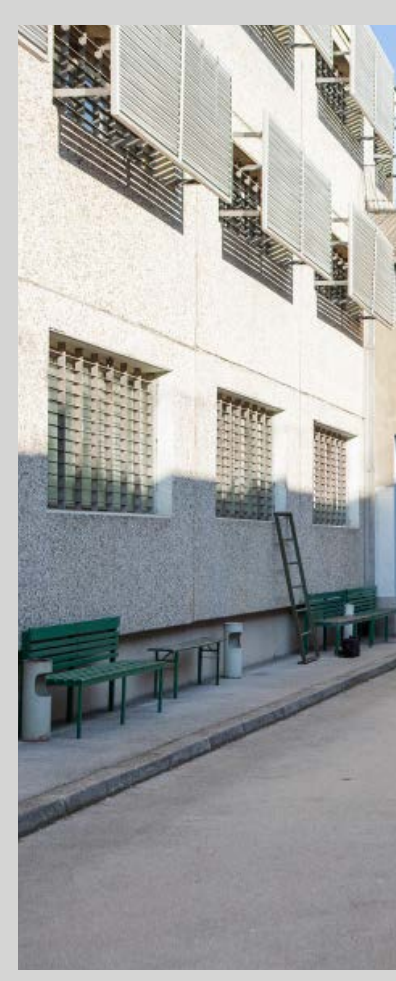




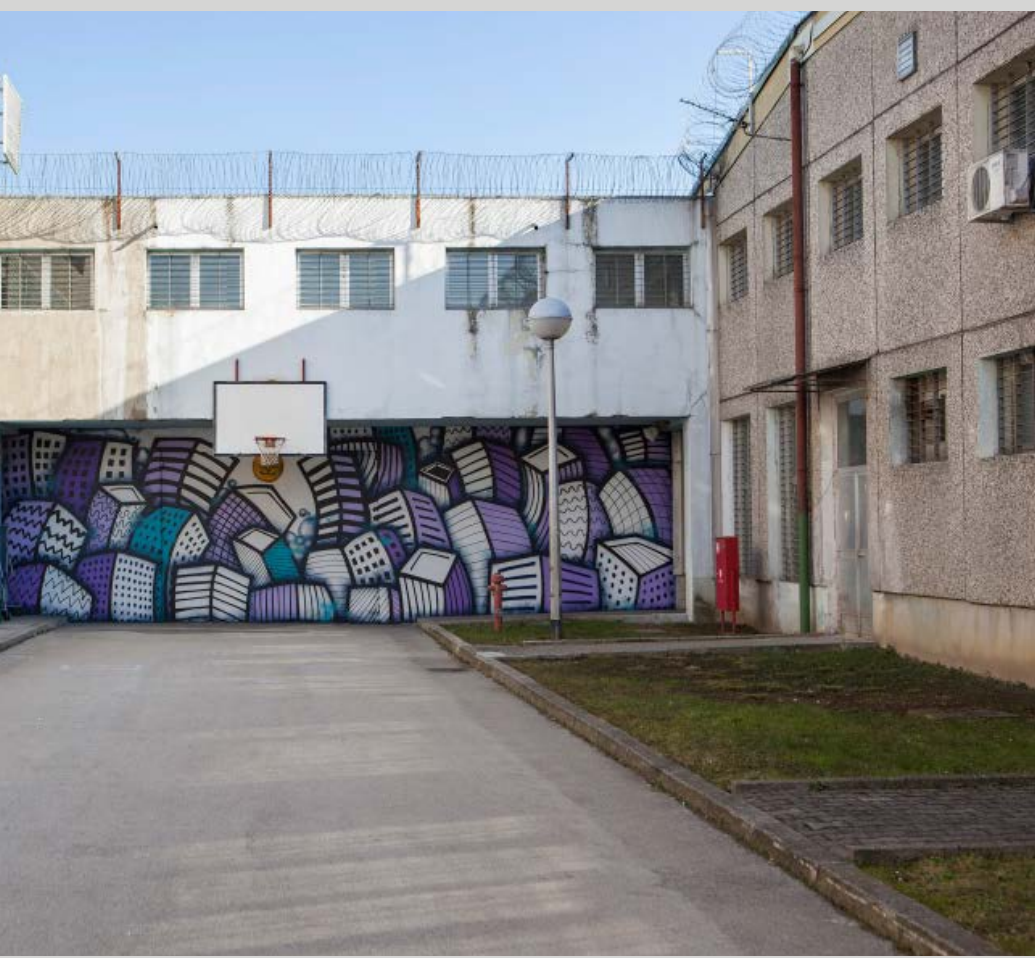

Slaven Lunar Kosanović, Heroji [Heroes], 2019. Foto/Photo: Ivo Kosanović @ HDLU
"TWO PERSONS COMING IN FOR ARTISTIC PAINTING" THE ETHNOGRAPHY OF PRISON AS A PLACE OF ART

Nakon nekoliko dana istraživanja u zatvoru, naviknule smo se na provjere i zapisivanja, ostavljanje mobitela i osobnih stvari na ulazu, a već smo mogle i predvidjeti koja će nas smjena na porti dočekati i najaviti kolegama riječima: „Dvije osobe ulaze za umjetničko oslikavanje." Bile smo članice projekta koji je uključivao izvedbu umjetničkih intervencija u Zatvoru u Zagrebu, popularno zvanom Remetinec, konkretnije, projektnog dijela koji se bavio terenskim istraživanjem samoga oslikavanja, praćenja rada umjetnika, kao i reakcija na umjetnička djela. Pojedinačno ili u paru, dolazile smo u zatvor iz dana u dan, na kraće ili duže vrijeme, te boravile tamo s četvero umjetnika koji su oslikavali prethodno izabrane i dogovorene zatvorske prostore. S obzirom na specifičnost i zatvorenost institucije, mogućnost terenskog istraživanja u zatvoru i uvida u život zatvorske zajednice činila nam se ekskluzivnom, gotovo na tragu izazova i otkrića kakvo su imali legendarni antropolozi poput Bronisława Malinowskog kada je kročio na Trobriandske otoke, u zajednicu njemu i većini društva stranu, nepoznatu i izoliranu od svijeta.

Projekt o kojemu je riječ-Revitalizacija zatvorskog prostora umjetnošću-osmislila je i vodila slikarica Melinda Šefčić u okviru europskog umjetničkog projekta CreArt-Network of Cities for Artistic Creation, ${ }^{1}$ kojem je nacionalni nositelj Hrvatsko društvo likovnih umjetnika. Polazište projekta bila je teza o pozitivnom utjecaju umjetnosti na percepciju okoliša u kojemu ljudi borave te ukupnoj pozitivnoj promjeni društva i pojedinaca koju umjetnost može potaknuti, kroz svoj estetski, društveni i afektivni aspekt. ${ }^{2} \mathrm{~S}$ tih je polazišta ovaj projekt postavio umjetnost u specifični okolišzatvor-i među specifične pojedince-zatvorenike. Projekt se počeo pripremati više od godinu i pol dana prije same izvedbe u veljači 2019. Prvi koraci bili su predstavljanje projekta Ministarstvu pravosuđa u čijoj su nadležnosti zatvori, odnosno predstavnicima Središnjeg ureda Uprave za zatvorski sustav, predstavnicima Zatvora u Zagrebu, Centra za dijagnostiku i Zatvorske bolnice. Razgovaralo se o zatvorskim prostorima u kojima bi se moglo realizirati oslikavanje, mogućnostima ostvarivanja kontakta s djelatnicima zatvora, prikladnom dobu dana za izvedbe intervencije, provedbi istraživanja te medijskom praćenju projekta. Tijekom pripreme uslijedila su još dva sastanka članova projekta-umjetnika i istraživača-s upravom i voditeljima odjela Zatvora u Zagrebu uz konkretnije razgovore o navedenim temama te uz obilazak zatvora i predstavljanja potencijalnih prostora u kojima bi se mogle izvesti umjetničke intervencije. Voditeljica projekta odabrala je četiri umjetnika, a skice radova koje su osmislili poslane su zatvorskoj upravi na uvid i odobrenje. Prilikom sastanka predstavljen je i istraživački segment projekta koji se sastojao od dvije dionice: kvalitativnog, terenskog istraživanja te kvantitativnog, anketnog istraživanja. ${ }^{3}$

Naše kvalitativno etnografsko istraživanje temeljilo se na kulturnoantropološkom pristupu i na metodama sudioničkog promatranja, otvorenih intervjua i neformalnih razgovora. To je istraživanje bilo određeno istraživačkim izazovom 
s kojim se dosad hrvatska etnologija i kulturna antropologija rijetko susretala, a ni nas tri istraživačice nismo imale iskustvo rada u istraživanju takvih institucija ili organizacija. Istraživanje zatvora, točnije istraživanje u zatvoru, pripada vrsti istraživanja koja nalažu drugačija pravila i mogućnosti uspostavljanja kontakta, slobode kretanja, otvaranja pojedinih tema i biranja sugovornika. Profesionalni i etički pristup u našoj struci inzistira na pomnom promišljanju odnosa povjerljivosti prema uvidima i saznanjima sakupljenima tijekom istraživanja, a na ovome specifičnom zatvorskom terenu taj je aspekt bio i dodatno istaknut. $U$ središte našeg istraživanja postavljene su umjetničke intervencije u zatvoru, umjetnici kao nositelji umjetničkih intervencija, zatvor kao mjesto umjetničkih intervencija i mjesto etnografskog istraživanja te razumijevanje konteksta kojim se stvorila privremena dinamika između umjetnika, istraživača i djelatnika zatvora (pravosudne policije, stručnih, tehničkih i administrativnih službi, konkretno policajaca, psihologa, pedagoga, socijalnih radnika, edukacijskog osoblja, liječnika, stomatologa, kuhara, čistačica) te ponekog zatvorenika u praćenom prolasku lokacijom umjetničke intervencije.

Pristupi istraživanju i interpretaciji proizlaze iz domena antropologije prostora te antropologije umjetnosti. Arhitektura Zatvora u Zagrebu, kao i gotovo svih drugih zatvora, oblikovana je tako da definira njegovu funkciju-s vanjske strane stroga zatvorenost ploha zidova, tamo gdje se i nalaze prozori, postavljene su, uz metalne rešetke na prozorima, vanjske betonske rešetkaste konstrukcije koje, iako razrahljuju masivnost vanjskih zidova, priječe pogled u zatvor. Unutarnji zatvorski prostor čine nizovi zgrada i nizovi prozora s rešetkama, a unutarnje prostore definiraju hodnici s vratima u zatvorske sobe i rešetke između prolaza u pojedine odjele, kao i nekoliko zatvorskih dvorišta između zgrada. Zatvorski prostor, kako je to u svojoj studiji o „rađanju zatvora" pokazao Michel Foucault, ${ }^{4}$ strogo je definiran svojim arhitektonskim sastavnicama, oblikovan kako bi definirao neslobodu, disciplinu, pravila, ograničenja, strogoću, nadzor i kontrolu. Uvođenje umjetničkih intervencija u zatvor radi estetizacije prostora pa onda posljedično stvaranja ugodnosti, i to kroz aktivnost-umjetnost-koju par excellence definira kreativnost, nesputanost, sloboda, zaigranost, nekonvencionalnost, gotovo je nespojivo s poimanjem zatvora. Polazeći od antropološke postavke da se određenim aktivnostima u fizički, materijalni prostor upisuju nova simbolička značenja, ${ }^{5}$ fokusiramo se upravo na nova i izmijenjena značenja koja umjetničke intervencije stvaraju u doživljaju, percepciji i iskustvu bivanja u zatvoru. Ta nam je perspektiva omogućila da u prostoru u kojem pratimo neobičnu i nesvakidašnju akciju zabilježimo trenutke u kojima se izmjenjuju i dodiruju dvije ideje prostora-strogo definirana, naučena, očekivana i življena praksa zatvorskog prostora s jedne strane i druga, izmaknuta vizija prostora koja pomiče granice društvene ideje zatvora, potiče razmatranje i onoga što je očekivano i onoga što je neočekivano u takvom prostoru, promišljanje o samom zatvoru, o umjetnosti, kao i o umjetničkim intervencijama u zatvoru.
Takav pristup prostoru preoznačenom umjetničkim intervencijama također proizlazi iz temeljnih postulata antropologije umjetnosti, koja umjetnost sagledava kao kulturni sustav određen svjetonazorom grupe unutar koje se ostvaruje, pri čemu se individualnim činovima pripisuju kolektivna značenja, te je smješta u kontekst svih ostalih ljudskih iskustava, aktivnosti i izričaja. ${ }^{6}$ Antropološko viđenje umjetničkog djela polazi od shvaćanja njegove estetike kao svojstva koje nije imanentno djelu, već se o njemu pregovara u složenoj mreži društvenih aktera, kulturnih politika, lokalnih i globalnih znanja, načina života i osobnih. Suvremene postavke antropologije umjetnosti u središte pozornosti stavljaju djelatnu komponentu umjetnosti, njezin potencijal da ostavi dojam, izazove učinak i afekt, generira društvene procese te izmijeni doživljaj okoliša i društvenu dinamiku unutar grupe koja je stvara. ' Upravo ova posljednja odrednica umjetnosti kao agensa, shvaćanje sukreatorske uloge zajednice u kojoj i za koju umjetnost nastaje, potiče istraživače da analiziraju kako umjetnička djela izazivaju promjenu, ali ujedno kako sudjelovanje u umjetničkom procesu može rezultirati transformacijom pojedinaca i grupe. ${ }^{8}$

Ove su nam dvije subdisciplinarne antropološke sfere omogućile da promotrimo kakvu su novu značenjsku razinu inicirale umjetničke intervencije, stvorivši od zatvora mjesto umjetnosti.

\section{O ZATVORU \\ I UMJETNOSTI}

Uz dominantna istraživanja zatvora i u zatvorima koja primarno vezujemo uz pravne znanosti, kriminologiju, rehabilitacijsko-edukacijske i psihološke studije te studije iz područja socijalnoga rada, niz je drugih znanosti koje se bave nekim aspektom penalnih institucija. Sociološka, antropološka i filozofska istraživanja pažnju su usmjeravala na istraživanje povijesti ideje zatvora, kritike koncepta zatvora kao institucije društvene kontrole i discipliniranja, odnosno totalne institucije te asimetrijskog odnosa moći dviju najprepoznatljivijih skupina zatvorskih aktera-onih koje se čuva i njihovih čuvara. ${ }^{9}$ Nadalje, u novije vrijeme, discipline kulturne geografije, arhitekture, urbanizma i dizajna, u suradnji s kriminolozima i pravnim stručnjacima, zatvor promišljaju kao mjesto, prostor i fizičku lokaciju, izgrađeni okoliš koji u sebi uključuje pripadajuće objekte, kao i ljude koji u njemu rade i borave. Ta istraživanja sagledavaju ulogu zatvora posredno, tako da propituju načine na koje estetsko oblikovanje prostora i objekata u njemu pridonosi „sigurnosnoj i racionalnoj" ulozi zatvora, ali i potencijalnom prometanju zatvora u ozdravljujući prostor, što je uvriježeni način promatranja zdravstvenih ustanova, ali ne i institucija poput zatvora i kaznionica. ${ }^{10}$ Takav pristup karakterizira projekt „Strahom prožeto okružje ili potencijal za rehabilitiranje? Zatvorska arhitektura, dizajn i tehnologija i življeno iskustvo zatvorskih prostora", koji proučava estetske dosege suvremene zatvorske arhitekture. ${ }^{11}$ Na primjeru norveškog zatvora Halden istraživači pokazuju da se arhitektura zatvora ne mora temeljiti na ideji tamnice. Taj je zatvor 
osmišljen kao otvorena arhitektura koja se vodi maksimalnom osvijetljenošću unutrašnjih prostora i promiče ideju da zatvori mogu biti lijepi. Osim estetskim promišljanjem, projektanti zatvora Halden vodili su se idejom humanosti, ljudskih prava i poštovanja. Ti su principi, posebice onaj estetski, suprotni funkcionalističkoj ideji zatvorskog prostora kao zatvorene, nezanimljive i stroge arhitekture koja stvara osjećaj izdvojenosti i izoliranosti. Kompleksi izgrađeni od betonskih blokova te sigurnosnog plašta kojim se zatvor odvaja od vanjskog svijeta upisuju u arhitekturu stavove šire zajednice o izolaciji pojedinaca od društva kao kazni, a o kažnjenicima kao ljudima koje treba zatvoriti, zauzdati i nadzirati. ${ }^{12}$ Time se proizvode prostori izolacije, izdvajanja, pritvora, kaznionica, centara za izobrazbu, odgojnih zavoda, odnosno prostori bitno određeni ograničavanjem kretanja u njima. U njima se pažnja istraživača usredotočuje na odnos između prostornih politika koje uspostavlja institucija i otjelovljenog prostora koji u njemu realiziraju različite osobe. Načini na koji se načela ograničavanja kretanja, zatvaranja i izdvajanja upisuju u tijelo zatvorenika predstavljaju središnji interes nove zatvorske geografije. ${ }^{13}$ Odnos prostora i čovjeka te njihova međusobna uvjetovanost u specifičnom zatvorskom kontekstu u središtu je i ovog našeg antropološkog razmatranja.

Tek se u novije vrijeme pojavljuju i studije koje propituju mjesto umjetnosti u zatvoru. Tematski broj časopisa Scottish Justice Matters iz 2014. godine, posvećen odnosu umjetnosti i pravde, otvorio je problematiku umjetničkih inicijativa u zatvorskim ustanovama. Pitanja koja autori postavljaju tiču se sustvaranja umjetnosti u koje su uključeni zatvorenici i nositelji kreativnih inicijativa koje se pokreću izvan zatvorskog sustava kako bi potaknule promjene u okolišu i kod ljudi koji borave i rade u zatvoru. Autori također tematiziraju samootkriće umjetničkog dara među zatvorenicima na poticaj kreativnih programa (glazbenih, kazališnih, dramskih, spisateljskih, slikarskih). Projekti poput onog pod naslovom „Inspiriranje promjene”, koji se u škotskim zatvorima provodio od 2010. godine u cilju promicanja obrazovanja, podizanja pismenosti i razvoja umjetničkih potencijala u zatvorima, pokazao je da se takve umjetničke inicijative često usmjeravaju isključivo na zatvorenike, ostavljajući po strani ostale dionike, prije svega djelatnike zatvora. ${ }^{14}$ Evaluacija tog projekta ukazala je na nedomišljenost participativnog segmenta koji je, izostavljanjem zaposlenika zatvora iz sudjelovanja u kreativnim praksama, propustio njih adresirati kao dionike kreativne promjene koju inicira umjetnost u zatvoru.

Nadalje, recentne studije umjetnosti u zatvorima donose rezultate participativnih projekata u kojima se poticalo likovno izražavanje zatvorenika i rad na kreativnosti kao dio rehabilitacijskog procesa i reformacije zatvorskog sustava. Njihovi se zaključci temelje na kvantitativnim i kvalitativnim istraživanjima „zatvorske umjetnosti”, na istraživanjima tzv. „zatvorenika umjetnika”, djelovanju tzv. „zatvorskih umjetničkih studija”, zatvorskih programa „kreativne rehabilitacije” i "reinvencije zatvorenika” umjetnošću. ${ }^{15}$ 
Zagrebački projekt „Revitalizacija zatvorskog prostora umjetnošću" koji smo popratile etnografskim istraživanjem ima drugačiji pristup od prethodno opisanih. Njegov je primarni cilj estetska intervencija umjetnošću u zatvorski prostor koja nastoji izmijeniti doživljaj tog prostora i njegove konotacije, a manje participacija koja se temelji na aktivnostima zatvorenika, odnosno buđenju kreativnosti zatvorenika i sudjelovanju u umjetničkoj proizvodnji. ${ }^{16}$ Za razliku od projekata koji su fokusirani na odnos zatvorenika i umjetnosti, ovaj zagrebački projekt uzima ravnopravno u obzir sve one kojima je zatvor radna ili životna domena-osim zatvorenika, to su i svi djelatnici zatvora. Smještanje umjetnosti u zatvorski prostor i njezina komunikacija sa zatvorskom zajednicom bio je fokus našeg istraživanja, a upravo uključivanjem etnografskog istraživanja koje se odvijalo u zatvoru u samome tijeku umjetničkih intervencija ovaj je projekt unio novitet u hrvatska zatvorska istraživanja.

\section{ETNOGRAF KAO POSJETITELJ: METODOLOGIJA ISTRAŽIVANJA U ZATVORIMA}

„Antropološki ulaz u zatvor”, prema američkoj antropologinji Lorni Rhodes, obilježen je promišljanjem o metodološkim mogućnostima etnografskog istraživanja u zatvoru. ${ }^{17}$ Propituje se u kojoj je mjeri moguće izvesti istraživanja koja inače podrazumijevaju dugotrajnu uključenost u život promatranog sustava te kako se antropolog pozicionira u tom sustavu, s obzirom na postojanje dviju osnovnih pozicija -zatvorenika i djelatnika. Loïc Wacquant, francuski socijalni antropolog, u svojem je radu naglasio kako je u istraživanjima zatvorskog sustava potrebno napraviti iskorak na način da se „uđe u zatvor” i u njemu provede „intenzivno ,promatranje iz blizine'” kako bi se razumjeli složeni odnosi koji se ostvaruju u zatvoru, dobili „fino ocrtani portreti” zatvorskog života, iskustveni uvidi u zatvorsku svakodnevicu, strategije življenja i preživljavanja u tom, za antropologe jedinstvenom, društvenom prostoru. ${ }^{18}$

Na koji smo način provele svoje istraživanje umjetničkih intervencija u Zatvoru u Zagrebu? Nakon duge pripreme, sastanaka s nadležnim tijelima i projektnih sastanaka, terensko istraživanje u zatvoru izvedeno je kao niz poludnevnih etnografskih „susreta” u ukupnom trajanju od tri tjedna (veljača 2019.) u kojem smo naizmjence posjećivale zatvor, boravile u njemu, točnije na lokacijama umjetničkih intervencija, pratile rad umjetnika i provodile intervjue s njima, promatrale interakciju umjetnika i umjetničkog rada u nastajanju s onima koji su prolazili prostorom, komunicirale s djelatnicima zatvora koji su u obavljanju svakodnevnih poslova prolazili kroz mjesta intervencija. S djelatnicima stručnih službi i djelatnicima osiguranja provedeno je nekoliko intervjua tijekom oslikavanja. Također je s vremenskim odmakom (ožujak 2019.) organiziran grupni razgovor s djelatnicama stručne službe koje u novooslikanoj prostoriji provode redovite terapijske aktivnosti sa zatvorenicima. Prateći doživljaje, usputne komentare, upadice, impresije ili geste onih u prolazu, naša je etnografija bila ograničena „slučajnošću” interakcija s

\section{6}

Uz navedeni, nekoliko je još projekata koje je pokrenula voditeljica Melinda Šefčić u svrhu uvođenja umjetnosti u hrvatske zatvorske sustave, s time da neki projekti imaju istaknutiju dimenziju participacije zatvorenika u samome umjetničkom stvaranju, posebice tamo gdje se oslikavaju sobe i zajedničke prostorije zatvorenika, te kroz likovne radionice, usp. o projektu u ženskoj kaznionici u Požegi, Šefčić, Uzorna kaznionica.

17

Rhodes, „Toward an Anthropology of Prisons”. 18

Wacquant, ,The Curious Eclipse of Prison Ethnography”, 385-386. 19

Ugelvik, „Prison Ethnography as Lived Experience”.

20

Jandrić Nišević, „Rezultati percepcije interijera Zatvora”. 
djelatnicima ili ponekim zatvorenikom s jedne strane, dok je s druge strane za uspješnost istraživanja iznimno važna bila otvorenost uprave i pristupačnost djelatnika $s$ kojima smo privremeno dijelili prostor-njihov prostor rada bio je i naš prostor istraživanja.

Promišljanje o metodologiji bilo je sastavni dio naše pripreme od početka projekta. Pisanje o našem iskustvu „promatranja iz blizine" u Remetincu zahtijeva da predstavimo načine na koje smo istraživanje izvele i okolnosti proizašle iz sasvim neuobičajenoga etnografskog terena, a koje su uključivale nastojanje da što je moguće manje remetimo svakodnevicu zatvorskoga ritma iako smo, kao znanstvenice s odobrenjem da istražuju u zatvoru, samom svojom pojavom i boravljenjem predstavljale iznimku. Na svoje iskustvo referiramo se kao na svojevrsnu slobodu u neslobodi. Od prvoga je dana naša pozicija u zatvoru bila određena riječju „,posjetitelj", ispisanom na kartici koju smo dobile na ulazu i nosile na odjeći. Protokolizirani ulazak, pregled detektorom metala, predaja osobne elektroničke opreme i identifikacija koju je obavljao policijski službenik na ulazu svako su nas jutro preimenovali iz „profesionalnog stranca” u odobrenog posjetitelja. Uloga „posjetitelja” kao da je u tom kontekstu bila normalnija i očekivanija od uloge znanstvenika i „odgovornog profesionalca" koju smo tamo imale. ${ }^{19}$ Naše predstavljanje pri ulasku i u kontaktu s djelatnicima u prostoru zatvora bilo je svakodnevno inicirano uvijek iznova. Kretale smo se pod pratnjom jednog od djelatnika zatvora koji je bio zadužen za nas, nekad prepraćene pravosudnom policijom i slijedeći pravila korištenja prostorom. Ne ulaziti u određene odjele, zvoniti, najaviti se pri ulasku i izlasku iz pojedinih dijelova zgrade dežurnom odjelnom policajcu, čekati, propuštati prioritetno kretanje, diskretno se povući i ustupiti glavninu prostora pravosudnoj policiji koja se kreće sa zatvorenicima, pričekati da se obavi aktivnost koja podrazumijeva redovito funkcioniranje zatvora, tek onda ostvariti svoju vlastitu namjeru kretanja ili pozicioniranja u prostoru-takvi su postupci određivali našu zatvorsku etnografiju. Nakon nekoliko dana naša je početnička „potpuna nesloboda” kretanja, zamijenjena prvim dozvoljenim slobodnijim kretanjem izričito do punktova umjetničkih intervencija, iako je, kao i svako drugo kretanje u zatvoru, uvijek nadzirano. U sljedećim danima mnogi su nas djelatnici u okviru zatvorskoga prostora prepoznavali i propuštali, otvarajući nam vrata i prije nego što pozvonimo jer, kao su objasnili, „nas je već netko uočio, prepoznao i donio procjenu da nam se vrata mogu otvoriti". Tijekom vremena naša je prisutnost i kretanje između punktova oslikavanja gotovo normalizirana, iskazana i prijateljskom konstatacijom poput „Samo se prešetavate danas.” Taj je trenutak označio postizanje „totalnog prepoznavanja”, ali i našeg razumijevanja privilegije prema kojoj je naša prisutnost uvažena kao „posebna”, „izdvojena”, možda „neslobodno slobodna", u svakom slučaju, neobična kao i etnografija koja je nastajala pri istraživanju u zatvoru.

lako je riječ o sasvim specifičnom terenskom istraživačkom iskustvu u kojemu je klasična antropološka „Iokalna zajednica" zamijenjena državnom zatvorskom institucijom, tijekom istraživanja dogodili su se uobičajeni procesi familijarizacije sa (zatvorskom) zajednicom, djelatnicima, postupcima i ponašanjima te je nakon kratkog vremena naša prisutnost uz umjetnike u zatvorskim prostorima postala prihvaćena. To nam je omogućilo dublje uvide u dinamiku koju su umjetničke intervencije izazvale u zatvorskom prostoru. Za razliku od kvantitativnog istraživanja koje daje statističke omjere prihvaćenosti/neprihvaćenosti i zadovoljstva/nezadovoljstva osoba koje rade i borave u zatvoru, ${ }^{20}$ naše kvalitativno istraživanje kontekstualizira susret umjetnosti i zatvora. U daljnjem ćemo tekstu opisati kako se taj susret realizirao u različitim zatvorskim prostorima intervencijama četvorice likovnih umjetnika te kakvu je društvenu dinamiku i koje reakcije potaknulo pretvaranje zatvora u mjesto umjetnosti.

\section{ČETIRI}

UMJETNIČKE INTERVENCIJE U ZATVORU U ZAGREBU

\section{GORAN RAKIĆ, REFLEKSIJA SLOBODE}

Street artist Goran Rakić oslikao je zid na samome ulazu u zatvor, uz kolni ulaz i portu, vidljiv iz svih pozicija kolnog i pješačkog ulaza i izlaza. Prostor je to betonski nadsvođenog hodnika između dviju zatvorskih zgrada te međuprostor između izvanzatvorskog prostora koji je odvojen ulaznim vratima i zatvorskog prostora s objektima i dvorištem, odvojenog drugim kolnim vratima. U donjoj trećini zid je bio obojen beživotnom smeđom bojom, u srednjem dijelu bijelom, a u gornjoj su trećini toga visokoga zida prozori ureda pravosudnih policajca koji otuda rade provjeru svih koji ulaze i izlaze iz zatvora. Na oku imaju i prostoriju u zgradi preko puta, sobu u staklu u kojoj se zadržavaju novopridošli zatvorenici prije uvođenja u zatvor. Omeđen zgradama i vratima, ulazni je prostor izrazito taman, osim kada jedna od otvorenih kolnih vrata nakratko omoguće ulaz danjega svjetla. Upravo zbog takvoga karaktera prostora, umjetnik uz idejnu skicu rada Refleksija slobode ističe da mu je namjera:

\section{„suptilno estetizirati prostor, nenametljivom}

umjetnickom intervencijom, koja će se i tematikom

i bojama uklopiti u cjelinu ambijenta".

(Predstavljanje skica umjetnika, 2019.)

Valjkom na dugome štapu umjetnik je prvo, prateći kompoziciju skice, iscrtao glavne linije koje su se blago zavinute protezale cijelim zidom od dna do vrha. Potom su dijelom valjkom, a onda i sprejom nanesene tirkizna boja u međuprostorima iscrtanih linija na gornjoj polovici zida te boja breskve u donjoj. Dalje je umjetnik dorađivao rad sprejevima, stvarajući blage prijelaze između boja, nijansirajući dijelove slike, unoseći žutu, ljubičastu, zelenu boju, kraće i duže bijele linije, svjetloplave oblike nalik oblacima, bijele i tamnije zelene točke različitih veličina te razne nijanse bijele i sive koje su definirale osnovne, prvotno iscrtane zakrivljene linije rada. Cijelom kompozicijom umjetnik je želio postići „da ima neki flow po zidu, kao da nešto plovi”, a boje koje je izabrao donekle se odmiču od standarda za grafite, no boje su 


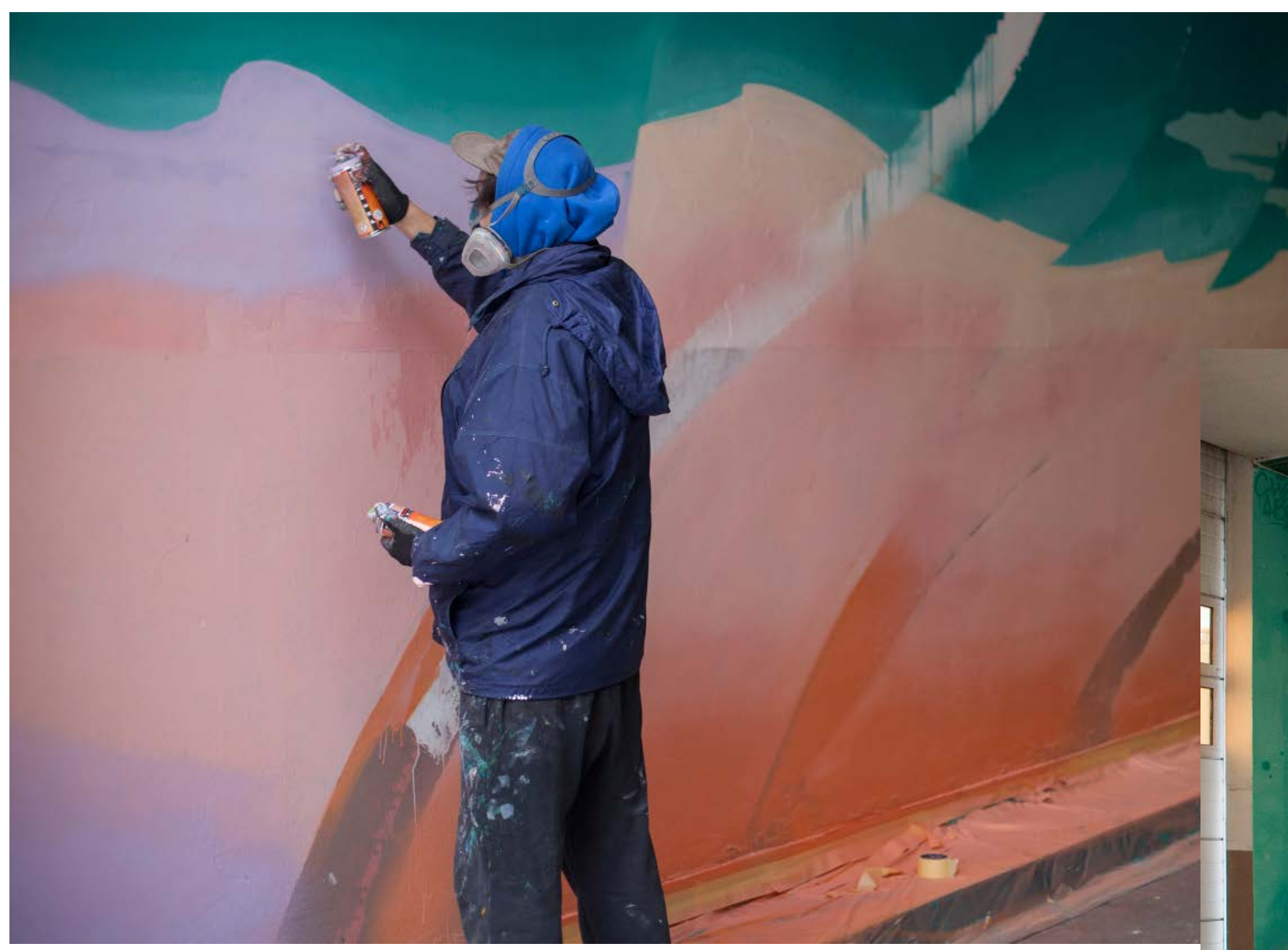

Oslikavanje ulaznog zatvorskog zida / The painting of the prison's entrance wall (G. Rakić). Foto/Photo: Ivo Kosanović (c) HDLU

$\uparrow$ 
to kojima se umjetnik u posljednje vrijeme više služi, svjetlije, pastelne boje, „da ništa ne iskače, zagasito, da bude blaže i ugodnije". Na muralu izostaju čvrste rubne linije, outovi, koji inače karakteriziraju grafite. Izvedba je osvojila cijeli zid, sve do prozora policijskog ureda, kao i cijevi na rubu zida. S obzirom na to da je ovaj ulazni prostor iznimno frekventan, umjetnik je rad često morao prekidati zbog ulaska i izlaska vozila, odmicati ljestve ili uklanjati boje. Pri toj frekvenciji kretanja, kada se jedna od dvojih kolnih vrata otvore, zid je osvijetljen i osunčan, što ga čini još mekšim i nježnijim.

Umjetnik je zid oslikavao dvaput: prva se izvedba, radi lošega stanja zida, vrlo brzo počela ljuštiti pa je odlučeno da se zid sanira i nanovo oslika. I prva i druga izvedba okvirno su se držale skice, iako nisu potpuno identične: najveća je razlika u izboru svjetlijih boja pri drugom oslikavanju. Osim toga, u prvome se radu umjetnik više koristio iscrtavanjem sjena linija stvarajući dojam trodimenzionalnosti, dok je u drugome radu to izostalo, a veći je broj manjih linija i točki. Rad po unaprijed dogovorenoj skici, i to još dva puta, za umjetnika je ograničavajući moment jer onemogućava njegov uobičajeni način rada koji uključuje postupnost i promjene koje se svakodnevno događaju prilikom crtanja murala, ovisno o inspiraciji, zidu, svjetlu i drugim okolnostima. Dodatna razlika u odnosu na slikanje vanjskih murala na uličnim zidovima u otvorenom prostoru jest činjenica da je u ovome zatvorenom prostoru, unatoč povremenom kratkotrajnom otvaranju kolnih vrata, tijekom izvedbe dominirao miris spreja.

\section{IVAN OŠTARČEVIĆ ZGUBLJEN, ADAPTACIJA}

Crtač i grafičar Ivan Oštarčević Zgubljen rad je izveo na dugačkom zidu hodnika koji povezuje zatvorske odjele i ćelije s dijelom zatvora u kojemu su prostorije za susret s posjetiteljima, djecom i odvjetnicima. U hodniku su vrata iza kojih se nalaze radne sobe djelatnika, sobe za suđenja videokomunikacijom i zatvorska knjižnica. Upravo zbog dijelova koje povezuje i prostorija koje se u njemu nalaze hodnik je izrazito tranzitni prostor, njime se kreću zatvorenici, policajci i drugi djelatnici zatvora. Pod hodnika je zelen, a donji dio zidova s obje strane obojen je svjetloplavom uljanom bojom u visini od oko metra i pol, do kvaka na vratima. Hodnik ima nekoliko prozora na kojima su vodoravne metalne rešetke te betonske vertikalne plohe s vanjske strane kao dio arhitektonske konstrukcije. Prozori čine ovaj hodnički prostor svijetlim unatoč njegovoj dužini.

Obrazlažući svoju idejnu skicu rada pod nazivom Adaptacija umjetnik navodi:

\footnotetext{
„Odabrani protagonisti su biljojedi, od onih pradavnih o kojima imamo saznanje preko fosilnih ostataka pa do današnjih s kojima koegzistiramo. Ogromni dugovrati dinosauri prisutni na lijevoj polovici zida uzeti su zbog svoje dobronamjernosti i miroljubivosti te jer nisu poznati po grabežljivosti,
}

a žirafe su prisutne na desnoj polovici zbog narativnog slijeda koji u zapadnjackoj tradiciji uvijek završava na desnom kraju. One su predstavnici evolucije - onoga što se prilagodilo svojoj novoj sredini. Kao i odabrani dinosauri, snemaju negativne konotacije, a prikazuju i tranziciju iz hladnih reptila u toplokrvne sisavce, odašiljući poruku smirenja i dobronamjernosti-empatije prema bližnjem. Dodatan je element na koji se mora skrenuti pozornost obilježje dugog vrata koji gledatelju omogućuje sudjelovanje u mirnijem životnom stilu na višoj nadmorskoj visini, nadrastajući nedaće svakodnevice i gledajući iznad onoga što je pred nama, pružajući pogled u budućnost."

(Predstavljanje skica umjetnika, 2019.)

Izvedba rada započela je postavljanjem crteža na zid, crtanjem dinosaura i žirafa ugljenom prema isprintanim predlošcima. Drugog se dana nanosila boja debelim kistom: boja breskve za životinje, plava boja za kućice amonita, izumrlih glavonožaca, te nježna žuta za međuprostor između likova "sladoledne boje”, kako objašnjava umjetnik, boje s dosta bijele kako bi imale nježni ton, stvorile „bajkovitost” i dale „dovoljno prostora imaginaciji”. Nakon nanošenja boja, kistom se iscrtavaju obrubi likova i druge linije koje naznačuju formu i oblik, oči, zube, šare na tijelu životinja, lišće paprati. Većina rada izvodi se stojeći na stolcu jer se oslikava gornji dio zida, dok donji ostaje definiran od prije postojećom plavom uljanom bojom koja je utjecala i na izbor boja i njihove nijanse $u$ samome radu, kako bi cjelina zida izgledala skladno. Na najvećem dijelu zida te su dvije plohe zida odvojene debelom ljubičastom crtom stvarajući dojam da se slika gleda preko ograde (donji plavi dio zida) u prostor koji djeluje kao park sa životinjama koje zainteresirano gledaju u prolaznika, miluju mladunčad ili žvaču lišće.

U odnosu na idejnu skicu rad nema većih izmjena ni u bojama ni u kompoziciji. Rad je to uz koji se hoda više no što se zastajkuje uz njega, no dužina kretanja niz oslikani hodnik dovodi do toga da se barem u nekom trenutku, ponekad jednostavno zbog promjene u monotonom ritmu hoda i prolaženja, glava prolaznika okrene prema velikim životinjama. Umjetnik, navodeći da je pazio na izbor boja i motiva, ističe da je stvorio nešto „blago i benevolentno”, što može izazvati samo pozitivne konotacije.

\section{DOMINIK VUKOVIĆ, POGLED U BOLJE SUTRA}

Ilustrator i grafičar Dominik Vuković oslikao je zidove u sobi za terapiju u kojoj se provode razgovori zatvorenika sa stručnim djelatnicima u okviru grupnih rehabilitacijskih programa. Soba je svijetla, s nizom prozora s rešetkama koji gledaju na unutrašnje zatvorsko dvorište kvadratnog oblika, okruženo zgradama s ćelijama, s pogledom na zavojitu i kružnu stazu kojom šeću zatvorenici u vrijeme kada im je dozvoljeno. Zatvorenici u sobama međusobno komuniciraju glasnim 
dovikivanjem i komentiranjem, a uključeni su i oni na šetnici. Pogled u daljinu s toga prozora prelazi preko rolane žilet-žice na zgradi i dalje prema Sljemenu. Ružičasto obojena soba sadržavala je nekoliko stolica, pisaći stol, nekoliko odloženih računala, umivaonik s ogledalom i slike koje su naslikali zatvorenici-tri karikature i tri slike s pejzažnim motivima.

Objašnjavajući idejnu skicu rada Pogled u bolje sutra, koja je nastala u okviru šire aktualne autorske tematske izložbene serije Hahari i žabe, umjetnik obrazlaže izbor motiva u odnosu na specifičnu namjenu prostora, kao i karakter korisnika:
„Kako je to soba za rehabilitaciju, ljudi u njoj razgovaraju i motiviraju se da osvijeste svoje traume iz života koje su ih stavile na krivi put. Motive iz djetinjstva i prirode vežem uz želju za napredak i rast te težnju za unutarnjom promjenom. [...] $\mathrm{Na}$ zidu $s$ prozorom prikazujem motive iz prirode. Smatram kako je boravak u prirodi smirujuć $i$ san o tome da se slobodno ljudi kreću njome izvan zatvora osuđenike može potaknuti na novi početak i težnju za promjenom. Na drugom su zidu motivi iz djetinjstva. Smatram da kada iznutra vodimo dijalog sa sobom, ne osjećamo godine koje imamo, samo se naše tijelo mijenja, dok naš duh ostaje jak i čist kao i kada smo bili djeca."

(Predstavljanje skica umjetnika, 2019.)

Prije oslikavanja umjetnik je pripremio zid, obojio ga je u bijelo da crtež bude uočljiviji, a u bijelu je boju dodao i kap žute kako bi dobio toplu bijelu nijansu koja više odgovara namjeni sobe od hladne bijele. Tek je trostruki sloj takve bijele pokrio raniju ružičastu boju zida, a svaki je od tri zida oslikan crtežima jedne dominantne boje-tako su nastali zeleni, smeđi i plavi zid. Zid ispod prozora ispunjen je motivima iz prirode u smeđoj boji-drveće, borovi, konji, jahači, poljska ograda, šumarci. Zid u zelenoj boji prikazuje razbacane zgrade nalik zagrebačkim donjogradskim „austrougarskim” blokovima između kojih se igraju djeca-lovice, nogomet, gumigumi, školica, puštanje zmajeva koji se susreću s golubovima, jatom gusaka, oblacima i balonom. Zid preko puta zelenoga plavi je „dječji zid” sa sličnim zgradama i grupom djece na biciklima iznad koje putuje cepelin. Za razliku od širokih poteza sprejom grafitera , Vuković crta kistom „iz zgloba”, sitne linije i detalje, prozorčiće na zgradama, tanke dječje likove, raspuštenu kosu, šilterice, odjeću, nasmijana lica.

Nastali u okviru umjetnikove autobiografske serije sjećanja na sretno djetinjstvo, crteži na zatvorskim zidovima izmijenjeni su utoliko što su izostavljani neki motivi koje umjetnik smatra „negativnima”, kao što su „školske tučnjave”, „razbijanje automobila”, „gađanje tramvaja grudama”, a zadržao je „impresije koje su pozitivne”. U izvedbi je izvorne skice dopunjavao elementima koji su u trenutku oslikavanja odgovarali dinamici scene koja je nastajala na zidu, držeći se principa rahlosti elemenata na bijelome zidu koji bi trebali poslužiti tek kao „niz asocijacija” koje gledatelj mora „staviti u kontekst” i ispričati svoju priču. 


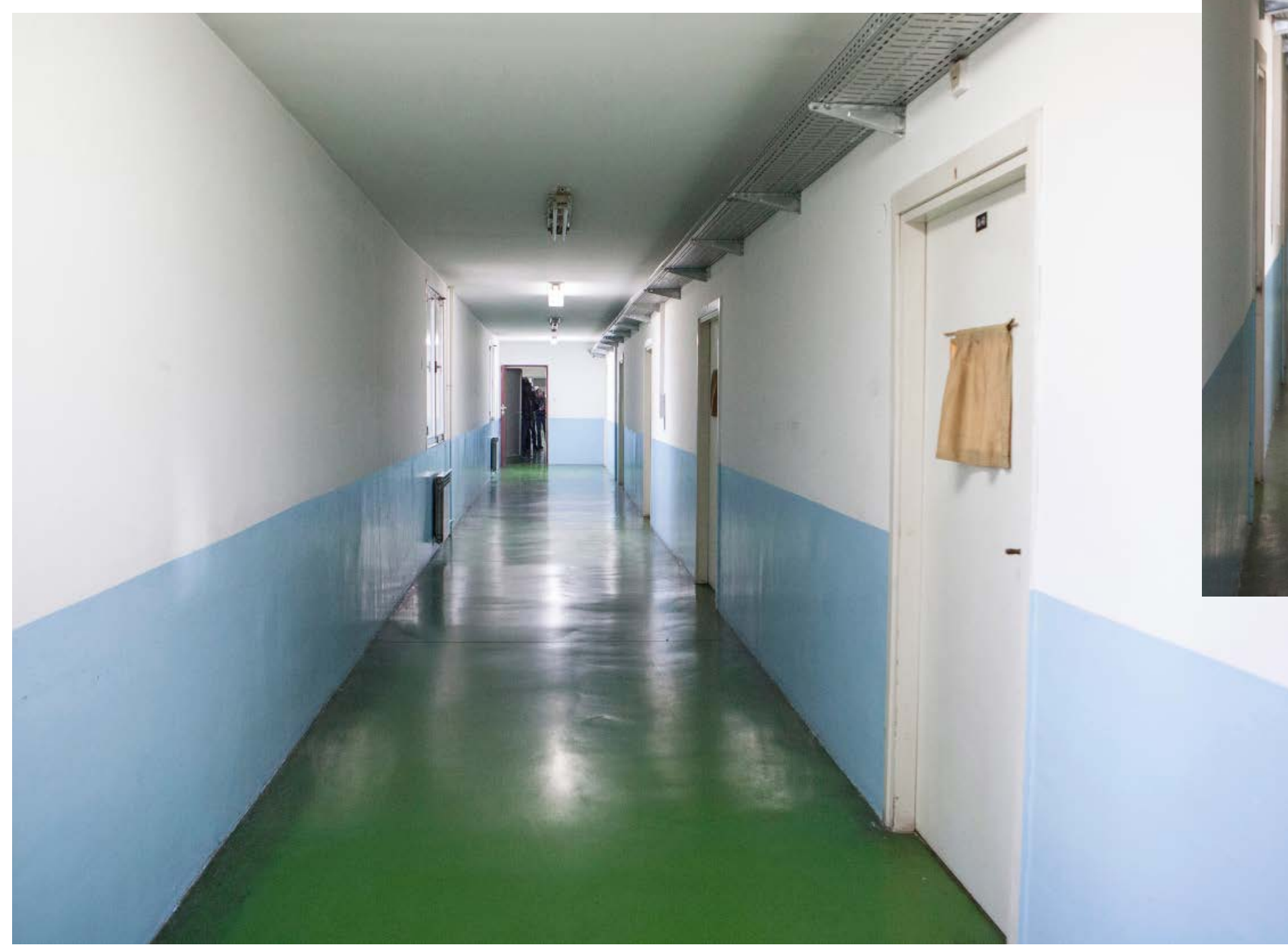

Hodnik prije umjetničke intervencije / The hall before the art intervention. Foto / Photo: Ivo Kosanović (c) HDLU 


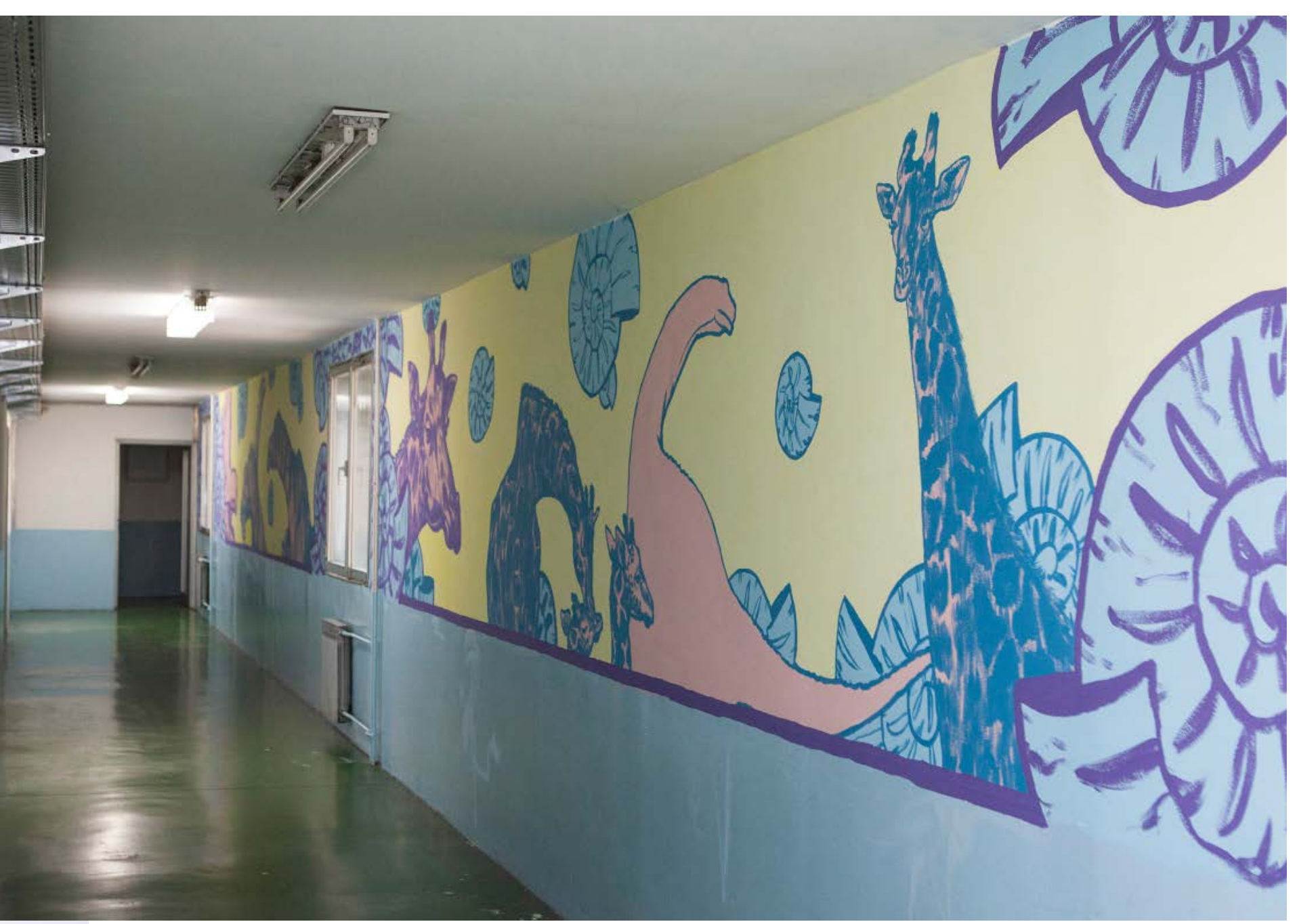

Ivan Oštarčević Zgubljen, Adaptacija [Adaptation], 20I9. Foto/Photo: Ivo Kosanović (c) HDLU 


\section{SLAVEN LUNAR KOSANOVIĆ, HEROJI}

Umjetnik grafita Slaven Lunar Kosanović svoj je rad izveo na zidu koji čini dio unutarnjeg dvorišnog zatvorskog prostora, a vidljiv je sa samoga ulaza u zatvor, kao i iz različitih pozicija kretanja djelatnika između zgrada, u dijelu dvorišta koje služi i kao šetaonica za zatvorenice. Na zidu se nalaze vrata koja vode prema vanjskim zatvorskim prostorima. Pri našem prvom dolasku, uz zid su stajale dvije klupe, sklopljeni stol za stolni tenis i odloženi namještaj. Zid je nadsvođen betonskim mostom na kojem se redaju prozori s rešetkama, a na središnjem dijelu konstrukcije postavljen je košarkaški koš: nadsvođenost štiti zid od padalina, a zid je zbog svoga poIožaja dobro osvijetljen velik dio dana.

Rad pod nazivom Heroji inspiriran je, prema riječima umjetnika, samim zatvorskim prostorom i pjesmom No More Heroes britanske punk grupe The Stranglers. Skica rada predstavlja prazan grad, „grad bez ljudi”, šarene zgrade s prozorima koje su nakrivljene prema središtu gdje stoji veliko žuto sunce na plavoj podlozi, a na košarkaškoj ploči ispisani su stihovi navedene pjesme: „Whatever happened to all of the heroes? All the Shakespearoes? They watched their Rome burn, whatever happened to the heroes?". Riječima umjetnika:

„Rad preispituje, kao što sam naslov kaže, gdje su nestali heroji. To dovodi u pitanje što ovi ljudi rade iza zidina, što ih je dovelo ovamo. To se može shvatiti kao prozivka, može se shvatiti kao apel na njihovu ljudskost. Zar stvarno nema nikoga od vas tko teži nekakvim herojskim djelima, nego djelima zbog kojih je izoliran iz zajednice, iz društva? I zato te zgrade tu neće imati likove koji inače veselo skakuću po većini mojih radova. Ovdje to neće biti, bit će jedno indiferentno sunce na sredini rada, koje će se pitati ovu rečenicu navedenu na muralu." (Predstavljanje skica umjetnika, 2019.)

Izvedba rada započela je iscrtavanjem kontura nakrivljenih zgrada crnim sprejom. Zgrade koje se izvijaju umjetnik koristi kao osnovni gradivni element rada, a koji ima za cilj predstaviti „pusti grad”. Slijedi nanošenje bijele fasadne boje na neke od ploha iscrtanih zgrada, dok su druge plohe obojene ljubičastom ili plavom bojom. Pri odabiru tamnije ili svjetlije nijanse boje umjetnik vodi računa o količini svjetlosti koja pada na pojedini dio zida. Potom su crnim sprejom podebljane rubne linije zgrada (,debeli outovi”), na nekima su oslikani redovi malih prozora, na drugima tanje ili deblje ravne ili zakrivljene crte. Na sredini zida oslikan je manji žuti krug s licem, prikaz koji autor naziva „indiferentno sunce”, ali može istovremeno asocirati i na Sunce i na Mjesec. Ponegdje između zgrada umjetnik je umetnuo plavkaste mrlje poput baIončića, koje objašnjava željom da se prepozna „da nije riječ o printu, nego o street-arterskoj izvedbi”. Velika dvokrilna željezna vrata, koja su ranije dominirala zidom, u kompoziciji i bojama rada više nisu bila uočljiva.
Zatvor u Zagrebu, osim na lokaciji Remetinec, uključuje i poluotvoreni odjel u Vukomercu, koji nije bio uključen u projekt i nije bio dio istraživanja.

22

U anketi je sudjelovalo I9 zatvorenika. 23 Jandrić Nišević, „Rezultati percepcije interijera Zatvora”, 5I. 24 Goffman, Asylums. 
Autor je već uz idejnu skicu naveo da će se „na licu mjesta doraditi te obogatiti detaljima u skladu sa zidnom površinom", te u samoj izvedbi pratimo neke izmjene: koloritnu skicu su zamijenile dominantno ljubičaste varijante boja; veći je broj izvinutih zgrada koje sada dominiraju muralom umjesto ranije centralno smještenog i velikoga žutog sunca; na skici su sve zgrade imale prozore, dok je u izvedbi dio zgrada dobio ravne ili savinute, vertikalne ili horizontalne, tanke ili debele crte (možda kao nesvjesni refleks tog dominantnog konstruktivnog elementa zatvorskog prostora-rešetki); na košarkaškoj je konstrukciji košarkaška mreža uklonjena kako bi se realizirao planirani natpis, no bijela ploča ostaje neispisana stihovima o herojima.

\section{AKCIJE, INTERAKCIJE \\ I REAKCIJE}

Zatvor, dakle, odnosno neki njegovi prostori postaju mjestom umjetnosti, a naše istraživanje i analiza prate simboličku transformaciju prostora i dinamiku koju je potaknula između različitih aktera. Riječ je o prostorima koji su, s jedne strane, prostori rada za mnoge djelatnike zatvora. Rad u zatvoru podrazumijeva smjene od osam ili dvanaest sati i svojevrsnu naviku, iako se radi u specifičnim prostornim i društvenim okolnostima; „u početku sve je šok”, a kasnije „,posao kao svaki drugi”. Možda „zbog oblika zgrade ili arhitekture”, objašnjava jedna djelatnica, prostor Remetinca djeluje „hladan i prazan", ali:

\section{„Ulazeći u prostor i prolazeći kroz prostor} nemam osjećaj nelagode. Možda sam nekad, pogotovo kad su se javile informacije o ovom projektu $i$ oslikavanju, jako počela razmisljati: ,Pa da, taj je prostor možda malo prazan, možda bi na zidovima moglo nešto biti."”

Druga je osoba također jasno artikulirala doživljaj prostora u kojemu radi: „nije bio neugodan, ali nismo razmišljali da može biti bolje":

\section{„Imamo osjećaj da kad radiš u zatvoru da prihvatiš prostor kao takav, sa željeznim zavjesama, s manjkom sunca, manjkom svjetla, sivim zidovima, bijelim zidovima, neutralnim bojama, prihvatiš ga kao takvog i niti ne razmisljaš da može biti drugačije.”}

S druge strane, zatvor je prostor zatvorenika. Konkretno, u vrijeme našega istraživanja Zatvor u Zagrebu imao je nešto više od 600 zatvorenika, što uključuje istražne zatvorenike i prekršajno zadržane osobe te zatvorenike i kažnjenike na izdržavanju kazne zatvora. Specifičnost ovoga zatvora, za razliku od kaznionica u kojima se kazne izdržavaju dugoročnije (npr. u Lepoglavi i Požegi), jest činjenica da veliki broj zatvorenika ostaje u Remetincu privremeno, nekoliko mjeseci dok traje istražni postupak ili pak nekoliko tjedana dok traje dijagnostički postupak. Takva velika fluktuacija ljudi utječe na dinamiku odnosa i familijariziranja u prostoru. ${ }^{21}$ Anketno istraživanje ${ }^{22}$ upućuje na činjenicu da $89 \%$ anketiranih zatvorenika doživljava prostor zatvora odbojnim, nezanimljivim i praznim. ${ }^{23}$ Iznimku čini zatvorski odjel na kojemu se služe pravomoćne kazne, odjel na kojemu su tijekom jednog od ranijih projekata uređeni hodnici, postavljene dekorativne naljepnice s afirmacijskim porukama, informativna ploča i sl., no većina zatvorskih prostora ostavlja dojam sivila. Je li moguće imati, kako je rekla jedna osoba u Remetincu, „zatvor veselih boja" i bi li takav zatvor banalizirao ozbiljnost i autoritet jedne „totalne institucije” ${ }^{24}$ koju u ključnome definiraju strogi nadzor i kontrola?

Međutim, iz razgovora s djelatnicima uočava se da su se i sami zatvori promijenili: neki su upućivali na činjenicu da sve više djelatnika ima visoko i šire obrazovanje, čime se mijenja njihov profil, drugi na mnoge mjere koje zatvorski sustavi čine u cilju novih pristupa, sadržajnosti i kvalitetne rehabilitacije, dok neki ističu da su mnogi djelatnici mlađe dobi, čime su njihovi stavovi prema životu i odnosima drugačiji nego kod starijih kolega. Svi su ti čimbenici mogli utjecati na prihvaćanje ideje oslikavanja zatvora, a od mnogih projekata koji se izvode u zatvoru, upravitelj zatvora istaknuo je posebnost upravo ovoga i njihovo svesrdno uključivanje posebice u trenutku kada su bili upoznati s idejama i skicama radova, u kojima su prepoznali potencijal komunikativnosti radova s prostorom, osobnim biografijama ili mogućnostima za introspekciju.

Četiri umjetnika izabrana su na temelju voditeljičina poznavanja njihova dotadašnjeg rada i angažmana u zajednici, prepoznavanja motiva i stila, a koji su odgovarali pretpostavkama art-terapije, okosnice u temeljima projekta. Umjetnici su se u tom smislu oslonili na znanje voditeljice te su bili skloni više ili manje prilagoditi radove specifičnim postavkama art-terapije (npr. izbjegavanjem agresivnih boja i oštrih linija), odnosno izborima onih boja, oblika, figura i sadržaja koji odgovaraju terapijskom učinku. lako su neki, kako slijedi iz razgovora s umjetnicima, razmišljali o reakcijama koje bi njihova intervencija mogla izazvati u zatvorskim uvjetima, ostaje pitanje može li se reakcija do kraja predvidjeti, posebice ako se umjetnošću komunicira u zatvorenom sustavu o kojemu nemamo pretjerano široko znanje, a budući konzumenti te umjetnosti u zatvoru nisu uobičajena publika.

Oslikavanje zatvora, višednevni boravak umjetnika u zatvorskim prostorima, bilo je ključna interakcijska razina i od samoga je početka izazvalo veliko zanimanje svih koji su prolazili. Jedan je od razloga taj što je riječ o vrlo neuobičajenoj aktivnosti u zatvorskom prostoru, pri čemu je oslikavanje izazvalo svojevrsnu „okupaciju” prostora-postavljanje najlona, ljestvi ili stolaca, boja, kistova i sprejeva te konstantnu prisutnost umjetnika i istraživača na lokaciji. Oslikavanje je spontano poticalo komunikaciju. Na početku oslikavanja najčešća je bila znatiželja, pitanja o tome što se radi, tko je organizirao i kakva će biti slika: umjetnici kažu da je to „small-talk folklor” uobičajen i tijekom drugih oslikavanja izvan zatvora. Zatvorenici su radove rijetko komentirali umjetniku, ali češće policajcu s kojim su se kretali kroz zatvorski prostor. Djelatnici su zatvora pak bili svakim danom 


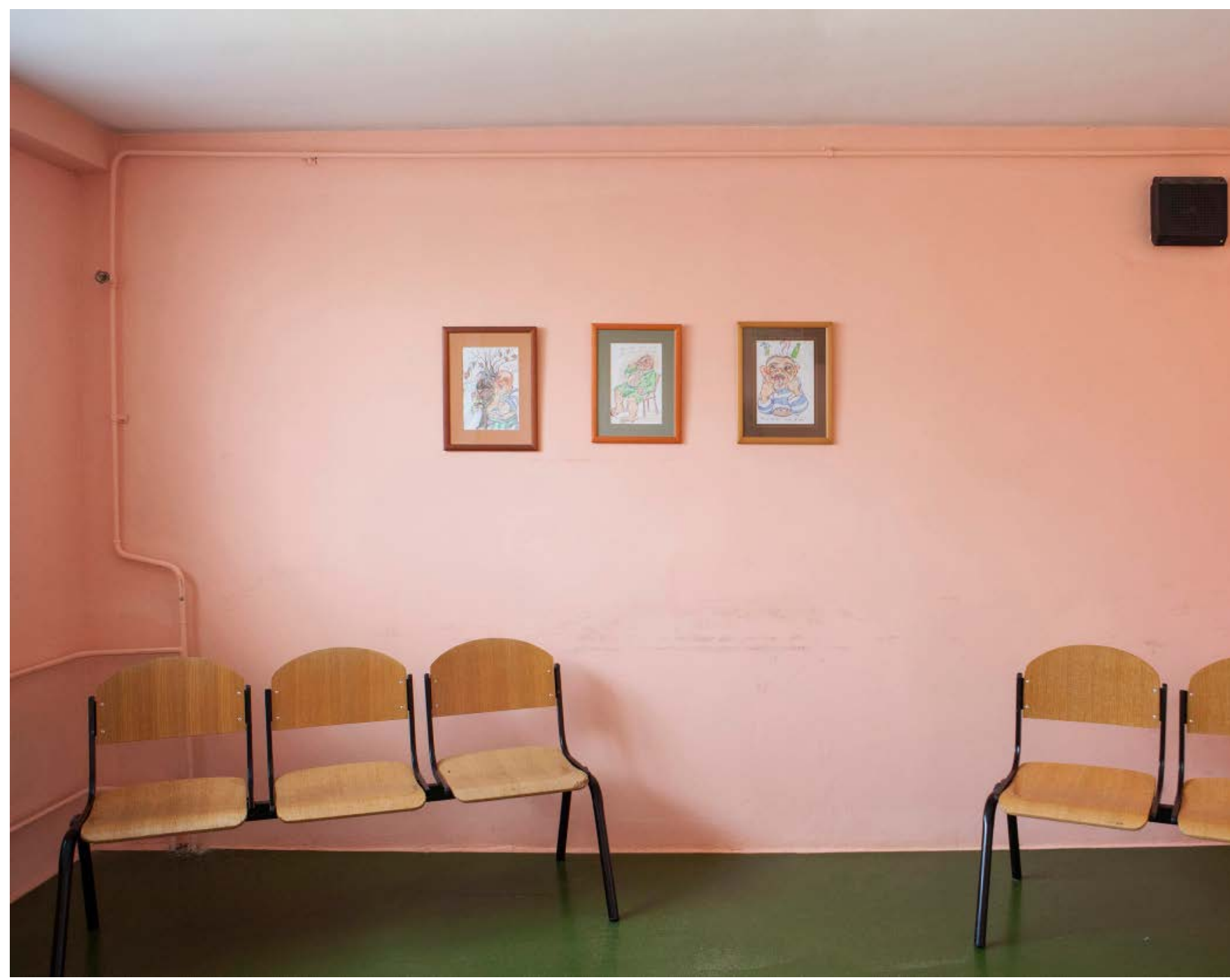

Soba za terapijske aktivnosti prije umjetničkih intervencija / The room for the therapeutic activities before the art intervention. Foto/Photo: Ivo Kosanović c HDLU

$\uparrow$ 

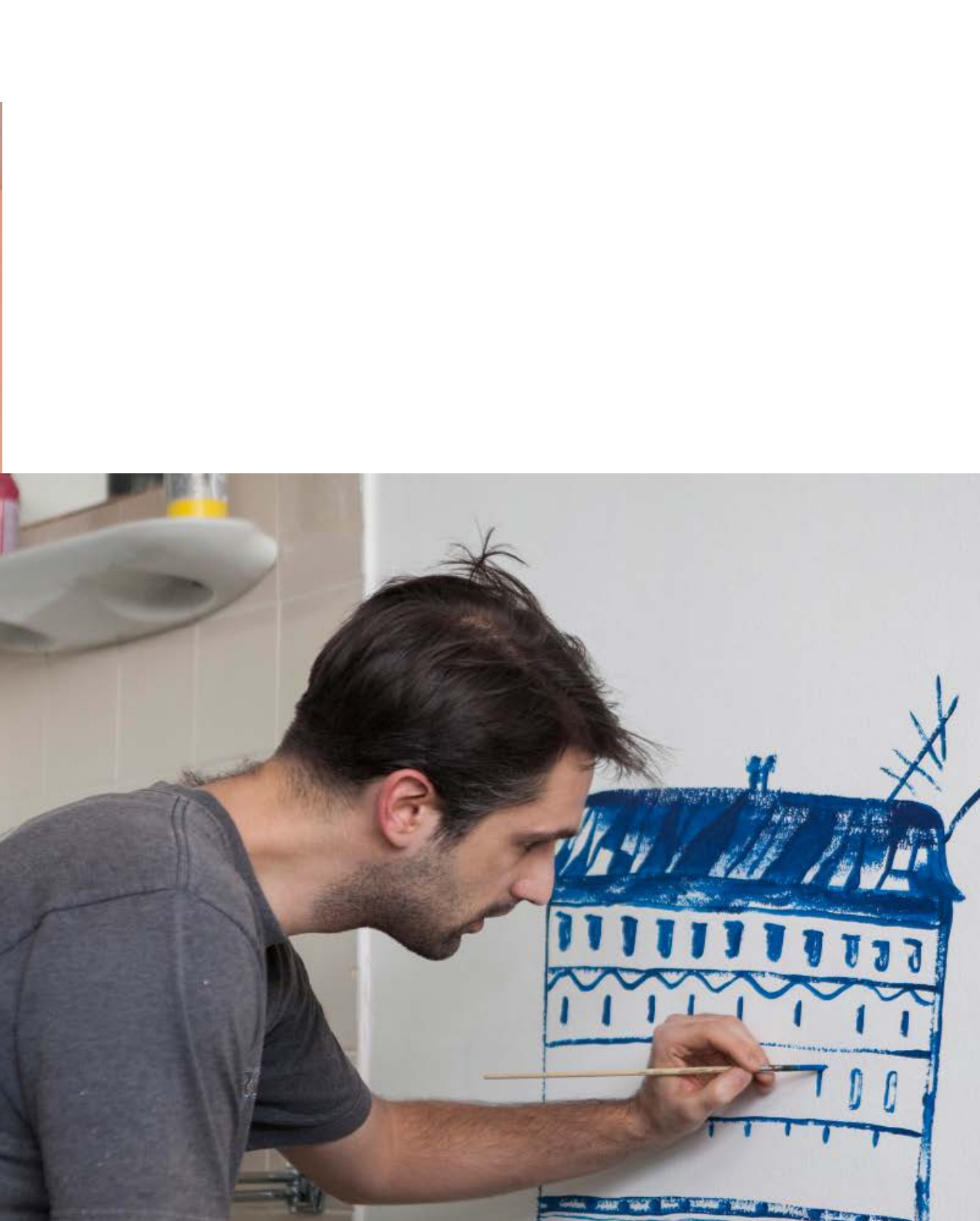

.

(a) ग11110\%ग
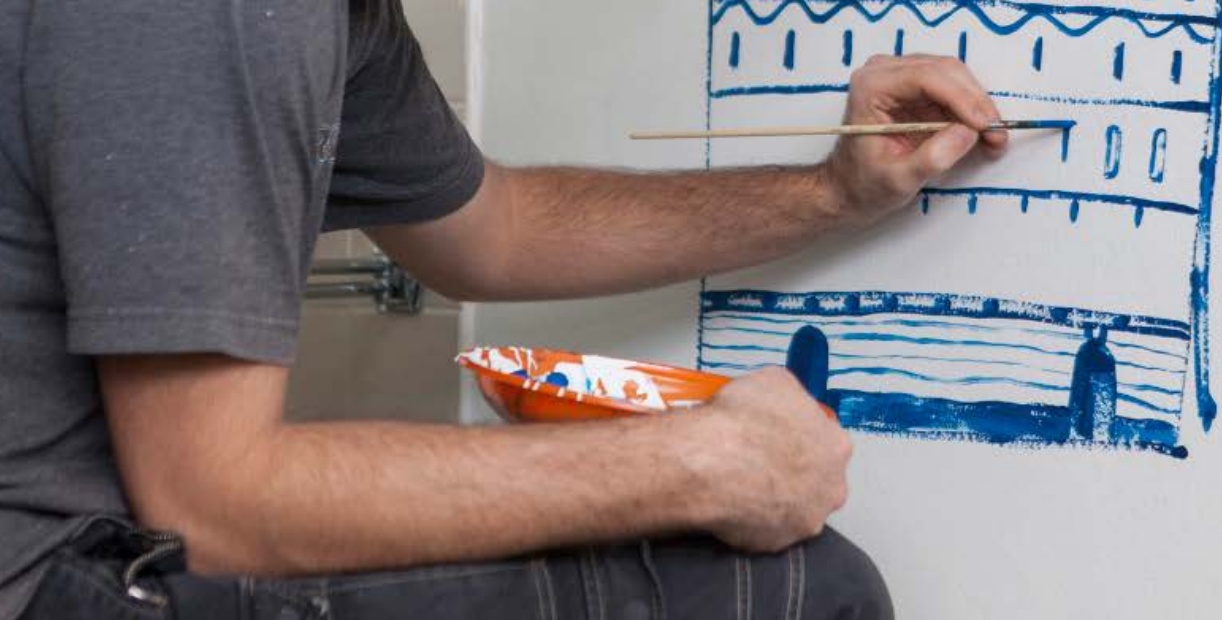

7)

1

Oslikavanje terapijske sobe / The pain Foto/Photo: Ivo Kosanović (c) HDLU

$\uparrow$ 
sve otvoreniji u davanju komentara kako su umjetnici i istraživači postajali dio zatvorske svakodnevice i mnogobrojnih dnevnih susreta. Dio komentara iskazivao je zadovoljstvo -bit će „Ijepše”, , ,ugodnije”, ,veselije”, ,„šarenije”. U trenucima nakon što su se počele nazirati prve konture slika iskazivala su se očekivanja što bi to moglo biti, a sve češće i što bi se htjelo vidjeti kao motive na zatvorskim zidovima, od realističnih do humorističkih (npr. vinograd, kleti, Plitvice, priroda, pejzaži, tigar na ulazu, Dinamov grb, ženski aktovi). lako je u nekim participativnim umjetničkim projektima predviđeno zajedničko kreiranje motiva, u ovome projektu to nije bio slučaj. Ne želeći „podilaziti širokom ukusu”, naglasak je bio na estetizaciji iz pozicije prepoznatih umjetničkih vrijednosti te na svojevrsnoj edukaciji tako da se unaprijed odabranim formatima i stilovima djeluje na rafiniranje umjetničkog senzibiliteta kod gledatelja. Ova in-situ komunikacija tijekom samoga oslikavanja umjetniku daje uvid u situiranost njegova djela u konkretnom društvenom i prostornom okviru, daje mu priliku, koju su umjetnici i iskoristili, da objasne onima koji su pokazali interes, najčešće djelatnicima-koji su se našli u ulozi publike-nešto više o konceptu svojega rada. Objašnjenje o tome kakvu priču priča zid, motivi i boje na njemu može dovesti do veće prihvaćenosti umjetnosti na neuobičajenim mjestima, koja ih tako i mijenja.

Odnos umjetnosti i zatvora, kao i reakcije na umjetničke intervencije, treba promatrati i kroz specifičnost prostora koji su postali lokacije konkretnih oslikavanja: ulaz u zatvor, hodnik, dvorište i terapijska soba. U svakome od ovih prostora umjetničke intervencije imaju različit odjek, ne isključivo zbog samoga umjetničkog djela, nego i zbog postojećeg karaktera prostora. Taj karakter ovisi o položaju unutar zatvora i funkciji konkretnog prostora, što oblikuje i komunikativnost prostora. Dinamike i karakter izabranih četiriju lokacija izrazito su različiti, od svojevrsne izoliranosti terapijske sobe, preko tranzitnosti ulaznog i hodničkog prostora do poluotvorenoga dvorišnog prostora. Sve to utječe na percepciju umjetničkoga djela u konkretnom prostoru. No reakcija je dvosmjerna jer umjetničko djelo utječe i na percepciju konkretnoga prostora mijenjajući-učvršćujući, propitujući ili invertirajući-značenja upisana u prostor.

Jedan primjer izmijenjenoga značenja koje je postalo prijeporno jest mural na ulazu u zatvor. Prije svega, mali broj djelatnika na ulazu, mahom pravosudnih policajaca, bio je upoznat s činjenicom da će se odvijati oslikavanje zida, a nije im bio poznat ni motiv slike. Stoga je prvoga dana oslikavanja bilo mnogo interesa za to što se radi, iskazanih pozitivnih reakcija očekivanja i novoga „poticaja za posao”, sugestija da bi prostor trebalo oslikati svijetlim bojama jer nema dovoljno dnevnoga svjetla, ali i upozorenja da je zid u lošemu stanju te da bi ga prvo trebalo sanirati. Sljedeći dan, kada je mural bio gotov, izvedba je doista bila narušena oronulim stanjem zida čiji su se dijelovi napuhali zbog novoga nanošenja boje, upotreba spreja izazvala je glavobolje u prostoru koji je većinu vremena bio zatvoren, apstraktni motiv murala nije bio razumljiv, izbor nježnih tonova (ružičasta boja) smatrao se neprikladnim za konkretan prostor, što se sve sažimalo u komentaru o neozbiljnosti (odnosno infantilizaciji i banalizaciji) naspram karakteru samoga ulaznoga prostora koji po funkciji mora biti stvarna i simbolička reprezentacija ozbiljnosti ustanove, kontrole, nadzora i autoriteta. Mural se, naime, nalazi na zidu na kojemu su i uredski prozori policijskoga nadzora i komunikacije sa svim zatvorenicima koji ulaze u zatvor i izlaze iz njega, točka prijelaza iz slobodnog u zatvorski život, liminalna zona čekanja zatvorskog prijama i kontrole osobnih podataka, mnogima prvi susret sa zatvorom. Policijski ured nalazi se na vrhu zida, dok svi koji dolaze stoje na cestovnoj razini, stvarajući tako i jaki hijerarhijski vertikalni dojam odnosa moći, koji je slikom narušen:
„Neozbiljna je slika... Baš je neozbiljno... Gore je dežurana, gore smo mi koji koordiniramo rad cijelog zatvora, onda mi ispadamo kao takvi neozbiljni... Neozbiljno je to što imaš dojam, kad sjediš gore $i$ kad te netko gleda odozdo, nemaś dojam da si došao u ozbiljnu ustanovu... Svatko tko izlazi, ja ga moram pitati tko je, što je, a sjedim gore, u gnijezdu'. Motiv bi trebao biti neki drugi, zamisljeno je OK, ali motiv neki drugi."

S druge strane, sasvim drugom prostornom registru-intimnijem i s manje nadzora-pripada tzv. terapijska soba, bez velike cirkulacije ljudi, namijenjena radu grupa zatvorenika i stručnih službi u provođenju tematski ciljanih rehabilitacijskih programa. Uz kaznenu, važna je uloga zatvora ona terapijska, korektivna, koja se usmjerava na promjenu obrazaca ponašanja zatvorenika i stvaranje boljih, društvu prilagođenijih pojedinaca. ${ }^{25}$ Utoliko je ideal zatvora, sveden na svoju ključnu rehabilitacijsku komponentu, obećanje boljeg, sigurnijeg svijeta ispunjenog pojedincima koji poštuju zakonska pravila i društvene vrijednosti. Upravo je naznaka toga boljeg svijeta, osobna preobrazba i vizija bolje budućnosti predočena motivima iz nekog sretnog djetinjstva kojima je oslikana terapijska soba. lako je naše pitanje bilo povezano i s mogućnošću da netko od zatvorenika ima traumatizirano djetinjstvo te odatle i negativnu reakciju, djelatnice stručnih službi nisu imale takvih iskustava:

„Ovaj prostor ovdje dobro je osmisljen, s ovakvim bojama kako je, nije nešto što te uspava ili oduzme koncentraciju, nego nešto što te ipak drži budnim i aktivnim u sudjelovanju... Ima puno tih detalja tako da stvarno mislim da prostor nije zamoran ili dosadan. Čini mi se da je pridonio poboljšanju. Ja nisam puno više ni očekivala od njih, ipak je to neka muska populacija, kriminalni milje, ne očekujete neke pjesničke duše, vrlo su rijetke pjesničke duše, ali nisam čula ni negativnih komentara, mislim da je nešto što im je novo, čišće, urednije i da može samo pozitivno utjecati na naš rad. Ja sam zadovoljna, a mislim da su i oni zadovoljni. Da nisu zadovoljni, rekli bi: ,Joj, kakva je to glupost’ ili nešto, prokomentirali bi. Rekli bi da ne valja." 
„Motivi su životni, mogu se zagledati u njih, ali ne odvlače pozornost s onoga što se radi, zato su dobro odabrane i boje i motivi."

„Kad su komentirali te slike, vratili su se u djetinjstvo, sjetili su se igre, skolice..."

„Mislim da nismo imale zatvorenika koji

bi se, kad boravi u tom prostoru, dignuo i rekao:

,Čujte, ja ne mogu' ili da je izašao iznimno

nesretan odavde. Naša svaka grupa, kad gledamo,

izlazi s osmjehom na licu, baš im je sve

bilo dobro..."

Umjetnikova je nakana i bila da prizori djece i djetinjstva „potaknu na razgovor". No rehabilitacijski, oslikani prostor može djelovati i svojom novom ili promijenjenom „energijom”, pa makar zbog puke inercije samoga boravka u prostoru. Već prvi razgovori stručnih djelatnica za tretman sa zatvorenicima u oslikanim prostorijama pokazuju da upućivanje na sliku izaziva ne samo pažljiviji odnos zatvorenika prema prostoru u kojemu se nalaze nego i reakcije kojima se motivi na slici povezuju s osobnim iskustvima, iskazuje interes i svojevrsno zadovoljstvo promjenom.

Vrlo mnogo reakcija izazvao je i mural u hodniku, „udarno mjesto" komunikacije između zatvorskih odjela i soba za komunikaciju s odvjetnicima, djecom i posjetiteljima, prostor čija je glavna funkcija prolazak, no s obzirom na svoju dužinu, gotovo je nemoguće ne primijetiti dinosaure i žirafe koje prolaznika prate duž kretanja hodnikom. Nekim je to bilo „osvježenje”, drugima na rubu uvredljivosti (s asocijacijom da je zatvor zoološki vrt ili Jurski park), treći intuitivno prepoznaju umjetnikovu nakanu oslikavanja evolucije koja vodi progresu pa u tome kontekstu vide i mogući napredak zatvorenika, četvrti šaljivo u oslikanim likovima prepoznaju svoje kolege, peti reagiraju iznenađenjem zbog slike i njezine živosti, neki uopće ne komentiraju riječima, nego gestikulacijom, stisnutim usnama i očima, stegnutim čelom i naginjući glavu od slike, drugi pri svakom prolasku hvale napredak oslikavanja ili komentiraju „energiju” koju je hodnik dobio oslikavanjem, posebice komparirajući ga s „tmurnim”, , „praznim”, ,tamnim” dijelom hodnika u koji dalje odlaze. Umjetnik zahvaljuje na pozitivnim komentarima i ignorira one negativne, smatra da je izabrao benevolentne motive te da ih svi tako trebaju i iščitati, odnosno "da nitko ne može imati neku lošu percepciju". No upravo motivi (koji nalikuju životinjama u slikovnicama), kao i odabrane nježnije boje (koje sam autor naziva „sladolednima”) generiraju najčešću opasku prolaznika djelatnika i zatvorenika, onu o tome da zatvor počinje sličiti na „dječji vrtić”. Najistaknutiji argument za takav stav jesu nježne, ružičaste i svijetle boje na muralima na ulazu i u hodniku, koje ne odgovaraju „mačističkom profilu zatvorenika", odnosno karakteru zatvora kao „mačo-institucije”, kako su to u nekim razgovorima obrazložili razni sugovornici, djelatnici i zatvorenici. „Pinky

boja”, kako je nazivaju, narušila je njihovu vlastitu percepciju zatvora kao čvrste i muške institucije. 


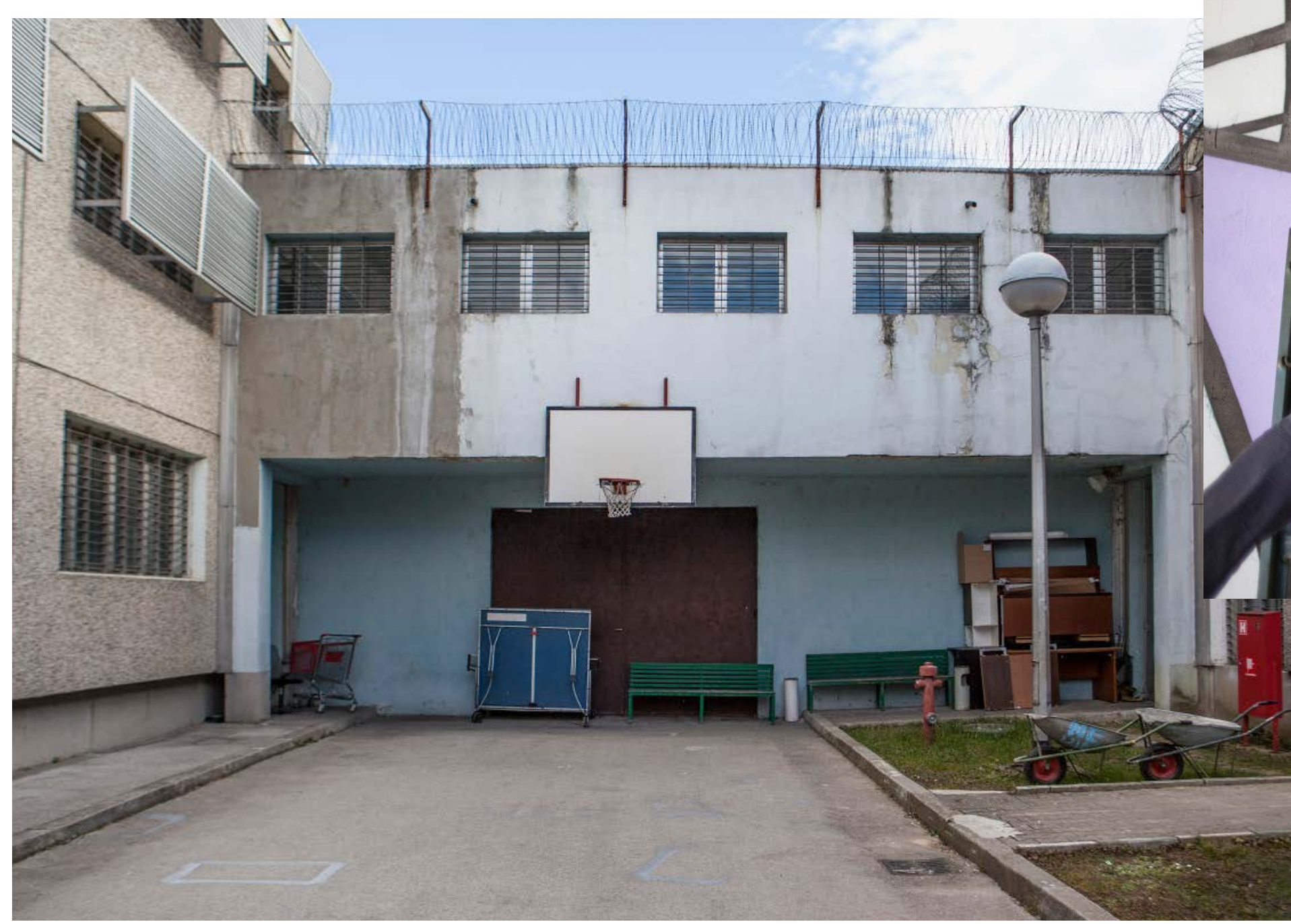

Dvorište prije umjetničke intervencije/ The yard before art intervention. Foto/Photo: Ivo Kosanović ( $)$ HDLU $\uparrow$ 


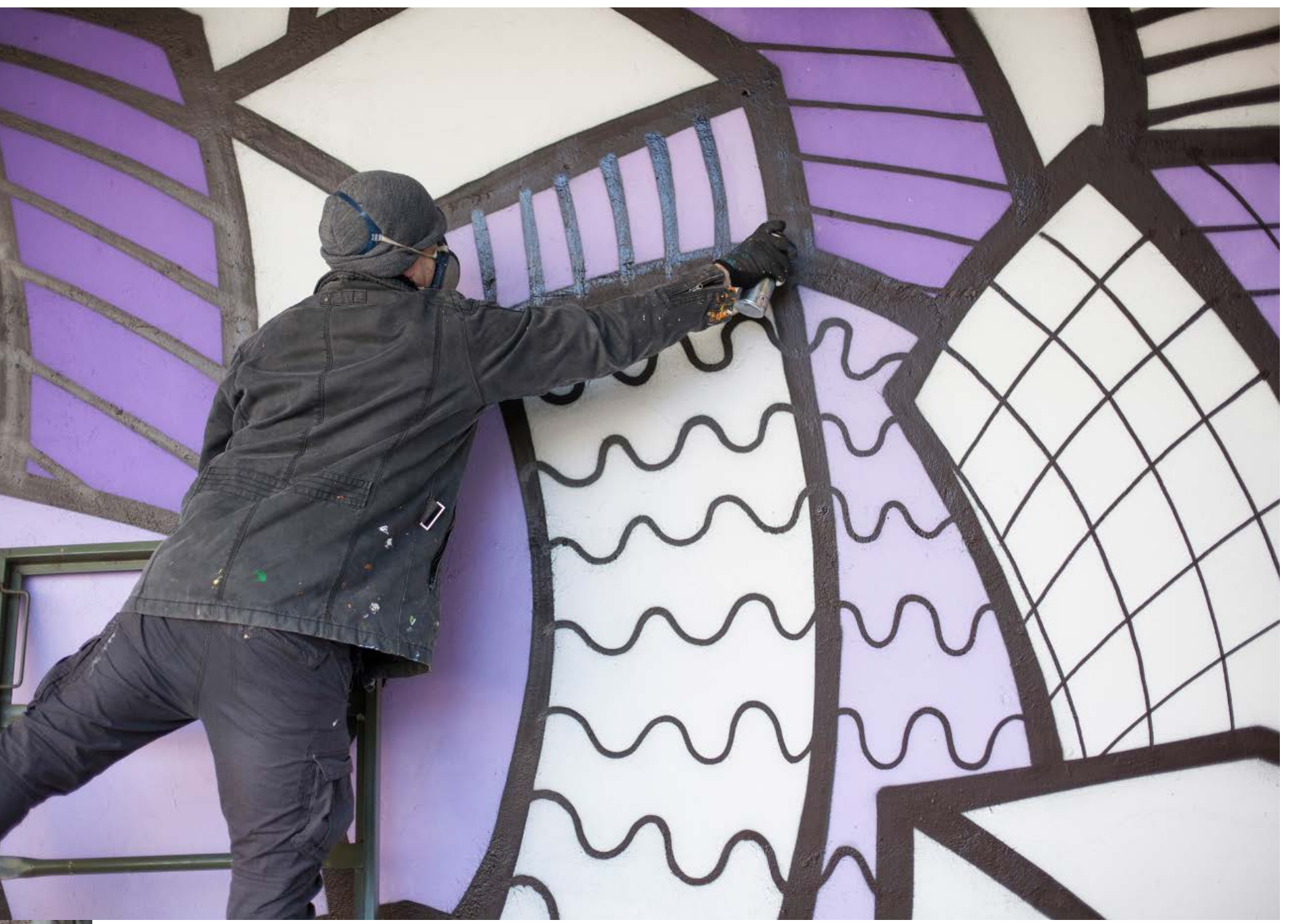
Foto/Photo: Ivo Kosanović ( ) HDLU 
lako istraživanje nije bilo usmjereno na razlikovanje komentara u rodnom smislu, jedan je komentar sažeo taj odnos prema oslikavanju: „muškarci su skeptičniji prema tome, a žene su tome naklonjenije". Zatvorenica je tek nekoliko desetaka u Zatvoru u Zagrebu, imaju svoj zaseban odjel i već pri prvom obilasku zatvora primijetile smo da je uređeniji od svih ostalih prostora. Na ulazu na Odjel nalazi se stolić s tabletićem i biljkama u teglama, slike su na zidovimariječima jedne policajke, stvorena je „domaća atmosfera”. Pravosudna policajka napominje da su umjetničke intervencije popravile „i prostor i raspoloženje” pri aktivnostima koje obavljaju, primjerice u situacijama u kojima moraju duže vrijeme na hodniku čekati zatvorenika. Jedna zatvorenica pak, u pratnji policajke, pristupa nam s oduševljenjem i komentira kako su žene (zatvorenice) jako pozitivne zbog oslikavanja, „očarane su onime vani” (mural u dvorištu na ženskoj šetnici), "divne su boje" i osvrćući se na oslikani hodnik napominje: „Evo, vidite što čini-da se sve tri osmjehujemo” (misleći na policajku, sebe i istraživačicu). I riječima i tijelom izrazila je jaku afektivnu reakciju na umjetnost, na njezinu agensnost, na ono što umjetnost čini.

Spomenuti mural u dvorištu nalazi se u dnu zatvorskog prostora te sama lokacija nije izrazito komunikativna u smislu prolaska kroz nju, ali je vidljiva iz različitih pozicija kretanja i bivanja u zatvoru, uostalom i zbog svoje veličine površine od oko $3,5 \mathrm{~m}$ visine i oko $20 \mathrm{~m}$ dužine. $\mathrm{U}$ tom prostoru zatvorenice provode svoj dvosatni dnevni period šetnjebile su oduševljene, kazuje pravosudna policajka: „Dirale su, gledale - što je to? Kao djeca”, iskazale su želju da i same oslikavaju. Vidljivost murala iz svih perspektiva dovela je do toga da su gotovo svi komentirali sliku i svima je odgovarala, kao da oko nje nije bilo razmimoilaženja u ukusima: svima se svidio motiv „plešućih zgrada”, dominantna ljubičasta boja (koja iako na prvu zvuči kao „ženska” boja, nije izazivala negativne reakcije), pokrivenost starih hrđavih vrata koja sa slikom više nisu bila vidljiva i karakter slike koji je procijenjen kao „urbani”, neki su čak u tim zgradama vidjeli sliku okolnog naselja i tako, u svojoj percepciji, napravili pretapanje zatvorskog i vanjskog prostora. To je i slika koja je doživjela najviše preinaka u odnosu na izvornu skicu: dokinut je kolorit, intenzitet boja i umjetnik je samoinicijativno reducirao boje na „dva tona ljubičaste”, veliko dominirajuće sunce koje je, riječima jedne djelatnice, „trebalo sve nas obasjati”, svelo se na - riječima umjetnika„indiferentno i poluapatično sunce”, a izostao je i natpis na košarkaškoj dasci koji bi motiv povezao s izvornom inspiracijom glazbenih punk-stihova. No taj je oslikani zid, barem kratkotrajno, doživio još neke izmjene, upravo one o kojima smo kao istraživačice razgovarale kao o mogućim intervencijama već prvoga dana praćenja oslikavanja. Naime, pretpostavile smo mogućnost da tijekom ili nakon oslikavanja netko iz zatvora nadoda neki detalj. S obzirom na to da su grafiti murali na uličnom prostoru otvorena prilika za intervenciju (za razliku od, primjerice, uokvirenih umjetničkih slika), taj je profil rada potencijalno i na zatvorskom zidu pozivao na slobodniju intervenciju. I doista se i dogodilo da je na muralu osvanuo šablonom izveden Dinamov grb, toliko

\section{6 \\ Gell, Art and Agency.} 27

Sličan smo uvid, o potrebi komunikacije s različitim razinama službi o planiranim umjetničkim intervencijama u složenim institucijama, imale i tijekom etnografskog istraživanja u okviru projekta oslikavanja prostora KBC-a Zagreb (Rebro) 20I7. godine, koji je također osmislila i vodila Melinda Šefčić, (usp. Šefčić i drugi, Estetizacija i humanizacija javnog prostora). 
često spomenuti motiv u prolazu, kao poticaj da ga se nekamo ubaci prilikom umjetničkog oslikavanja. To je sasvim zanimljiv paradoks koji govori o dozvoljenom i nedozvoljenom, počevši od činjenice da se crtanje grafita nekada smatralo vandalskim, nelegalnim i prekršajnim, a danas se uprizoruje u zatvorskom sustavu kao oblik estetizacije prostora; uostalom, upravo neki insajder „šara” po zidu i radi nedozvoljeno unutar strogo kontroliranog sustava. Dodatak je brzo uklonjen jer se organizatorima (HDLU-u i upravi zatvora) činio neprikladnim, no otvara pitanje o mogućnostima i takvoga prisvajanja slikarskih radova u prostoru zatvora tijekom vremena.

\section{ŽIVOT UMJETNOSTI \\ U ZATVORU}

Polazeći od postavki iz antropologije prostora i mjesta te antropologije umjetnosti po kojima umjetnost sama po sebi ima djelatnu ulogu u mijenjanju značenja prostora, u okviru projekta bavili smo se upravo istraživanjem te promjene in-situ u specifičnim okolnostima zatvorske institucije. Drugim riječima, zanimalo nas je što umjetnost čini (u) zatvoru.

Jedan moment toga novostvorenoga odnosa teško je i imenovati i izmjeriti jer je riječ o afektivnom osjećaju iskazanom u komentarima poput: „Prostor je bolji nego onaj koji je prije bio i to se osjeti" ili u drugome komentaru djelatnika koji podcrtava što se dalje događa s prostorom u kojemu su učinjene umjetničke intervencije:

„Prostor je kontinuirano uređen, dakle imate
onaj dojam da je čist i da je uredan, što jako pridonosi
da se vi bolje osjećate pa, vjerujem, onda i oni
[zatvorenici]. Od toga da su sad prozori kontinuirano
čisti, ništa nije zapušteno, ostavljeno, imam osjećaj
kao da svi odjednom vode veću brigu o prostoru
jer je uređen.”

Osim estetizacije prostora koja stvara afekt, umjetnički radovi imaju i potencijal terapijskog učinka, koji je u ovome projektu posebice zaživio u sobi za razgovore u kojoj motiv i stil slike djeluju poticajno za razgovore, kako komentiraju stručne djelatnice koje u tome prostoru rade sa zatvorenicima. Ta je intencija iskazana i u umjetnikovu promišljanju funkcije konkretnoga oslikavanja u zatvoru, odnosno šire, uloge umjetnosti:

\section{„Likovnost [je] jezik koji u sebi ima puno \\ komponenti. Neke su komponente edukativne, neke su informativne, neke te mogu oplemeniti. Ako moja likovnost uspije potaknut na neki razgovor o tim nekim stvarima, to je dobro."}

Umjetnost u zatvoru, koja ne samo estetizira nego i implicitno educira i potiče na novi senzibilitet prema umjetničkim djelima, dio je projektne agende. Ta je dimenzija možda ponajviše uočena u trenucima interakcija umjetnika i onih koji rade ili borave u zatvoru tijekom samoga oslikavanja.
Zapitkivanja o slici, interes za ono što se oslikava, komentiranje u prolazu, prilike su da umjetnik objasni i potakne sugovornika na promišljanje možda više nego da očekuje reakcije i viđenja svoje umjetnosti kako je sam zamislio. Riječ je o oslikavanju koje je teško usporedivo s nekim drugim okolnostima umjetničkoga rada: predstavljanje vlastite umjetnosti u zatvoru nije samo neobična prilika i dobra referencija u karijeri, nego zahtijeva složenu pripremu koja itekako traži razumijevanje ustanove, okolnosti, profila ljudi koji će tu umjetnost konzumirati, želju za angažmanom za dobrobit zajednice i pomno promišljanje o mogućim reakcijama, o djelovanju vlastite slike, njezinih motiva i boja, jer u zatvoru list iz prašumske šume može izgledati kao list marihuane, a ružičasta boja može djelovati omalovažavajuće. Pripisati to nerazumijevanju umjetnosti znači zauzimati ekskluzivistički stav koji nije odgovarajući intencijama ovakvog projekta. Stoga, nasuprot očekivanju da djelo govori samo za sebe, sasvim je smislen prijedlog jednog djelatnika da se uz slike na zidu stave legende s imenom autora i kratkim objašnjenjem motiva i značenja, čime bi se ponudio još jedan kanal za komunikaciju umjetnošću u zatvoru. Jer umjetnička intervencija, kao Gellovo sredstvo agensnosti, nepobitno proizvodi interakcije i reakcije, živi i izvan estetskog čina, samog estetskog djela, točnije u komunikaciji s publikom, ${ }^{26}$ koju u ovome slučaju čine zatvorenici i zatvorski djelatnici.

Komunikacija umjetnošću u zatvoru u okviru ovoga je projekta mnogodimenzionalna. Smjerala je s jedne strane ostvariti vidljivost umjetničkih institucija i umjetnika u njihovu djelovanju u javnom i društvenom životu, propitati dosege umjetnosti, no, ono što je važno, i potaknuti predstavnike institucija na promišljanje društvenog aspekta umjetnosti i njezine uloge u zatvorskoj zajednici, a time se povratno mijenja i percepcija zatvora u široj javnosti. U smislu realizacije, stoga je iznimno važna otvorenost institucije, s obzirom na to da je riječ o nekonvencionalnoj intervenciji koja se nekome izvana ili iznutra može činiti rubno prihvatljivom. Budući da je riječ o pomicanju granica u percepciji zatvora, kao i u njegovoj daljnjoj humanizaciji, ključna je podrška zatvorske uprave. No projekt je ukazao i na potrebu da se ideja oslikavanja pripremi i u širim okvirima komunikacije s djelatnicima. Više smo puta tijekom istraživanja za vrijeme oslikavanja razmišljale o potrebi i korisnosti istraživanja koje bi se izvelo prije intervencija. Naime, kvalitativno kulturnoantropološko istraživanje može dati uvide u potrebe, odnose i dinamiku unutar institucije, što umjetnicima može biti korisno za razumijevanje prostora u kojemu će raditi te za pripremu umjetničkih koncepata. ${ }^{27}$ Može biti korisno i za to da se bolje razumiju društvena očekivanja svih aktera, značenja koja pripisuju svojim prostorima rada ili boravka u zatvoru. Ključan doprinos kulturnoantropoloških istraživanja nadalje može biti upravo u sposobnosti etnografije da bilježi i promišlja učinke same umjetnosti ostvarene kao relacije i komunikacije. Time se stječu kontekstualizirani uvidi u mehanizme kojima se prostor mijenja estetizacijom i umjetnošću, a njegovi korisnici senzibiliziraju za promjenu, propitivanje i problematizaciju očekivanog. 
Očekivanja što zatvor jest i kakav treba biti također su ključni okviri promjene. Može li zatvor biti mjesto umjetnosti, mjesto veselih boja? Za koga je ta umjetnost? Čime su zatvorenici to zaslužili? Čiji se prostori uljepšavaju, oni za zatvorenike ili djelatnike? Je li potrebno uvoditi umjetnost u zatvore kada neke druge primarne stvari nisu cjelovito riješene? Može li zatvor bili lijepo mjesto? Pomak koji ostvaruje umjetnička intervencija u zatvoru potičući njegove svakodnevne korisnike na podizanje pogleda, reagiranje na umjetnički događaj i njegov ishod-umjetnički rad, sadržan je u trenutačnom remećenju očekivanja od toga što zatvor jest i što se od njega očekuje u percepciji onih koji rade ili borave u zatvoru, kao i u široj javnoj društvenoj percepciji zatvora i njegove uloge u društvu. Uostalom, što za sebe žele i što mogu očekivati djelatnici, a što zatvorenici kao sudionici jednog umjetničkog eksperimenta? Koliko takvoga remećenja očekivanoga i normalnosti može podnijeti zatvorska ustanova? U konkretnom projektu, i umjetnici i istraživači danima su „remetili” kretanje nekim prostorima u zatvoru, a i samom svojom prisutnošću bili su izazov zatvorskom redu. S druge strane, umjetnički i istraživački boravak vrlo je brzo normaliziran i prihvaćen, kao i slike koje su nakon nekog vremena djelovale kao da su „oduvijek” tamo. Medijski osvrti koji su popratili projekt odradili su onu razinu komunikacije s javnošću u kojoj se i zatvorski sustav, nasuprot slici krute i društveno izolirajuće institucije, predstavlja u novome svjetlu, kao otvoren sustav za nove pristupe, a istodobno na praktičnoj razini, uspješnost izvedbe ovoga projekta omogućuje lakše uvođenje sličnih intervencija u druge hrvatske zatvore i kaznionice.

O zatvorskom prostoru mislimo na razne načine, no misao o zatvoru kao izložbenom i galerijskom prostoru zacijelo nije jedno od učestalih poimanja. Sasvim sigurno da oslikani zidovi zatvora mogu biti "galerija” u trenutku posjeta neke delegacije kojoj se zatvor službeno predstavlja. No kada su djela izložena na nekima od najfrekventnijih punktova u zatvorskim prostorima, onda svi djelatnici, kao i zatvorenici koji svakodnevno dolaze u doticaj s umjetničkim djelom u prostoru-postaju specifična galerijska publika. Kao i svaka druga publika, i ova zatvorska galerijska publika heterogena je i reagira u čitavom nizu emocija i osvrta, od oduševljenosti do kritičnosti. Ono po čemu se ovaj galerijski prostor razlikuje od uobičajenih jest i po činjenici da je ta ista publika danima pratila umjetnički proces, komentirala rad u nastanku, od pripreme zida i oslikavanja kontura do nanošenja boje i finaliziranja rada. Trenutak ispisivanja potpisa na sliku, čin autorizacije, važan i za dojam izložbe, riječima jednog pravosudnog policajca, osvijestio je da su „djela unikati, a ovo je umjetnost"! Stoga ne čudi da je jedan djelatnik u prolasku oslikanim zatvorom, nakon što su umjetnici završili svoje radove, komentirao: „Izložba je otvorena.” Zatvor je postao mjesto umjetnosti. 
POPIS LITERATURE / BIBLIOGRAPHY

Čapo, Jasna, Gulin Zrnić, Valentina. „Oprostornjavanje antropološkog diskursa. Od metodološkog problema do epistemološkog zaokreta", 9-65. U: Mjesto, nemjesto: interdisciplinarna promišljanja prostora i kulture, ur. Jasna Čapo, Valentina Gulin Zrnić. Zagreb: Institut za etnologiju i folkloristiku, 2011.

Đurin, Sanja. „Lepoglavski Panoptikon-prostor, moć, identitet”, 269-285. U: Mjesto, nemjesto: interdisciplinarna promišljanja prostora i kulture, ur. Jasna Čapo, Valentina Gulin Zrnić. Zagreb: Institut za etnologiju i folkloristiku, 2011.

Foucault, Michel. Nadzor i kazna: Rađanje zatvora. Zagreb: Informator, 1994.

Geertz, Clifford. Local Knowledge. Further Essays in Interpretive Anthropology. New York: Basic Books, 1983.

Gell, Alfred. Art and Agency. An Anthropological Theory. Oxford-New York: Oxford University Press, 1998.

Goffman, Erving. Asylums: Essays on the Condition of the Social Situation of Mental Patients and Other Inmates. New York-Anchor Books, 1961.

Gulin Zrnić, Valentina, Potkonjak, Sanja, Škrbić Alempijević, Nevena. „Umjetnost i zatvor: kulturnoantropološko istraživanje”, 76-84. U: Revitalizacija zatvorskog prostora umjetnošću, katalog projekta, ur. Melinda Šefčić. Zagreb: Hrvatsko društvo likovnih umjetnika, 2019.

James, Franz. „,It's important to not lose myself'. Beds, Carceral Design and Woman's Everyday Life within Prison Cell", 151-176. U: Prison, Architecture and Humans, ur. Elisabeth Fransson, Francesca Giofrè, Berit Johnsen. Oslo: Cappelen Damm Akademisk, 2018.

Jandrić Nišević, Anita. „Rezultati percepcije interijera Zatvora u Zagrebu dobiveni na uzorku ispitanih zatvorenika i djelatnika Zatvora u Zagrebu prije i nakon izvođenja likovnih intervencija", 46-60. U: Revitalizacija zatvorskog prostora umjetnošću, katalog projekta, ur. Melinda Šefčić. Zagreb: Hrvatsko društvo likovnih umjetnika, 2019.

Jewkes, Yvonne, Moran, Dominique. „Should Prison Architecture Be Brutal, Bland or Beautiful?", Scottish Justice Matters 2, 1 (2014): 8-10.

Low, Setha M., Lawrence-Zúñiga, Denise, ur. The Anthropology of Space and Place. Locating Culture. Oxford: Blackwell Publishing, 2003.

Maxwell, Eliese. The Benefits of Prison Art: Providing Rehabilitation and Positive Implications. San Luis Obispo: California Polytechnic State University, 2017. https://digitalcommons.calpoly.edu/socssp/155 (pristupljeno 6. travnja 2019.)

Moran, Dominique, Turner, Jennifer, Schliehe, Anna. „Conceptualising the Carceral in carceral Geography", Progress in Human Geography 20, 10 (2017): 1-20.

Predstavljanje skica umjetnika za izvođenje likovnih intervencija u prostoru Zatvora u Zagrebu, rukopis, siječanj 2019.

Rhodes, Lorna A. „Toward an Anthropology of Prisons” ,Annual Review of Anthropology 30 (2001): 65-83.

Sparks, Richard, Anderson, Kirstin. „Evaluating Arts and Justice Initiatives. Inspiring Change". Scottish Justice Matters 2, 1 (2014): 5-7.
Sykes, Gresham. The Society of Captives. A Study of Maximum Security Prison. Princeton: Princeton University Press, 1958.

Šefčić, Melinda. „Revitalizacija zatvorskog prostora umjetnošću”, 5-7. U: Revitalizacija zatvorskog prostora umjetnošću, katalog projekta, ur. Melinda Šefčić. Zagreb: Hrvatsko društvo likovnih umjetnika, 2019.

Šefčić, Melinda, ur. Uzorna kaznionica. Zagreb: Hrvatsko društvo likovnih umjetnika, 2018.

Šefčić, Melinda, Gulin Zrnić, Valentina, Škrbić Alempijević, Nevena, Čapo, Jasna, Vrček, Mirna. Estetizacija i humanizacija javnog prostora: umjetnost kao terapija. Zagreb: Hrvatsko društvo likovnih umjetnika, 2017.

Ugelvik, Thomas. „Prison Ethnography as Lived Experience: Notes From the Diaries of a Beginner Let Loose in Oslo Prison", Qualitative Inquiry 20, 4 (2014): 471-480.

Wacquant, Loïc. „The Curious Eclipse of Prison Ethnography in the Age of Mass Incarceration", Ethnography 3, 4 (2002): 371-397. 
